\title{
Halyomorpha halys fixed as the type species of the genus Halyomorpha (Hemiptera: Heteroptera: Pentatomidae)
}

\author{
Petr KMENT ${ }^{1)}$, S. SALINI ${ }^{2)}$, Dávid RÉDEI ${ }^{3)} \&$ David RIDER ${ }^{4)}$ \\ 1) Department of Entomology, National Museum, Cirkusová 1740, CZ-193 00 Praha 9 - Horní Počernice, Czech Republic; e-mail: sigara@post.cz \\ 2) ICAR-National Bureau of Agricultural Insect Resources, Hebbal-560024, Bangalore, India; e-mail: shalinis.nilavu@gmail.com \\ 3) Department of Entomology, National Chung Hsing University, 250 Kuo Kuang Rd., 40227 Taichung, Taiwan; e-mail: david.redei@gmail.com \\ 4) Department of Entomology, North Dakota State University, Fargo, North Dakota, USA; e-mail: david.rider@ndsu.edu
}

Accepted:

$20^{\text {th }}$ December 2021

Published online: $31^{\text {th }}$ December 2021

\begin{abstract}
The genus Halyomorpha Mayr, 1864 (Hemiptera: Heteroptera: Pentatomidae: Pentatominae: Cappaeini) was established based on a single species, Halys timorensis Westwood, 1837 (currently a junior subjective synonym of Halyomorpha picus (Fabricius, 1794)). The examination of the voucher specimens identified as Halyomorpha timorensis by Mayr, a syntype of Halys timorensis, and syntypes of Pentatoma halys Stål, 1855 revealed that: i) Halyomorpha timorensis (Westwood), stat. restit., must be reinstated as a valid species, and not considered as a junior subjective synonym of $H$. picus; ii) Mayr's specimens belong to two different species, Halyomorpha halys (Stål) and H. picus. The problem of double misidentification of the type species of Halyomorpha is resolved by action of the first revising author(s) according to the Article 70.3 of the ICZN (1999): we fix here Pentatoma halys Stål, 1855 (= Halys timorensis sensu Mayr, nec Westwood) as the type species of Halyomorpha Mayr, 1864. A list of 36 valid species currently placed in Halyomorpha and their synonyms is compiled. We also issue a warning concerning the use of the citizen science approach for monitoring H. halys in Southeast Asia (which may also apply to other taxa): It is necessary to keep in mind that $H$. halys belongs to a group of habitually similar species (distributed from Pakistan and southern China to Indonesia and the Philippines) which cannot be identified with certainty without examination of their male genitalia; records merely based on observations or habitus photographs cannot be accepted as reliable.
\end{abstract}

Key words. Hemiptera, Heteroptera, Pentatomomorpha, Pentatomidae, brown marmorated stink bug, action of first reviser, nomenclature, taxonomy, type species fixation, China, Timor, Oriental Region, Palearctic Region

\section{Introduction}

Shield bugs (Pentatomidae) are the third most diverse family of Heteroptera, including nine subfamilies, 950 genera and nearly 5000 described species (RIDER et al. 2018, ROCA-CusACHS et al. 2021a). While recent papers have given a first insight into the phylogenetic relationships among the included taxa (GENEvCIUS et al. 2021, Roca-CuSACHS et al. 2021a, Xu et al. 2021), promising a revolution in the internal classification of the family, poor knowledge on the alpha-taxonomy still renders identification of many species impossible. While the situation concerning the New World fauna has improved significantly in the past sixty years due to the work primarily of Herbert Ruckes (1895-1965), Lawrence H. Rolston (1922-2008), Jocelia Grazia and the next generation of hemipterists inspired by their work (e.g., ROLSTON \& RidER 1985, RidER \& EGER 1995, GRAZIA et al. 2015, RidER et al. 2018, Guidoti et al. 2021), the knowledge of Pentatomidae systematics in the Old World tropics is more than unsatisfactory. Since 2015, we register only eight papers dealing with Pentatomidae fauna of the Afrotropical Region (KMENT 2015, KMENT \& BAENA 2015, KMENT \& Rider 2015, KMENT \& GARBELOTTO 2016, RidER 2016, KMent \& RÉDei 2018, Roell et al. 2019, Silva et al. 2021), 24 papers concerning the fauna of the Oriental Region (including southern China) (GHATE 2015; SALINI 
\& VirAKTAMATH 2015; SHAikH et al. 2015; HaSSAN et al. 2016; ZHAO et al. 2016; SALINI 2016a,b, 2017a,b, 2019; RÉDEI 2017; RoCA-CUSACHS et al. 2018, 2019; SALINI \& SCHMIDT 2018; AHMAD et al. 2019; IsHIKAWA \& MoriYA 2019; RocA-CuSACHS \& Jung 2019; RÉDEI \& TSAI 2021; Roca-Cusachs et al. 2021b; SALINI et al. 2021a,b,c,d; Salini \& KMEnt 2021; Salini \& Roca-Cusachs 2021), and only two on Australia (FAÚNDEZ \& RIDER 2018, 2019). However, none of the taxonomic papers mentioned above provided a revision of a species-rich genus.

Such an unsatisfactory situation concerns also Halyomorpha Mayr, 1864, a quite large genus currently containing 35 valid species (KMENT et al. 2021; a checklist is provided in the present paper), the monophyly of which has never been demonstrated. It is indigenous to the tropical and subtropical areas of the Old World from Senegal and South Africa in the west to Japan and New Caledonia in the east. Although the entire genus has never been revised, three regional revisions are available: that of LINNAVUORI (1982) concerning west and central Africa, that of AHMAD \& ZAIDI (1989) for the Indo-Pakistan subcontinent, and the work of HASAN (1993) for the Malayan subregion. The latter two papers, however, are taxonomically highly problematic (cf. KMENT et al. 2021). One of the included species, Halyomorpha halys (Stål, 1855), also known as the brown marmorated stink bug, has recently been introduced to North America, the West Palearctic Region and Chile, and it is actively expanding to new areas (e.g., HoEbeKe \& CARTER 2003, Wermelinger et al. 2008, FAÚNDEZ \& RidER 2017, HAMILTON et al. 2018, LESKEY \& NiELSEN 2018, GARIEPY et al. 2021, vAN DER HEYdEN et al. 2021). As a serious emerging pest, $H$. halys was attracting much attention in the last decade with dozens of papers published on various aspects of its biology every year (e.g., HAMiLton et al. 2018, LeSKey \& NiELSEN 2018). The male and female genitalia, necessary for a reliable identification, were accurately described and illustrated for $H$. halys only by VÉTEK et al. (2014), and for H. picus (Fabricius, 1794) by SALINI et al. (2021a) and Kment et al. (2021). Recent doubtful records of the invasive $H$. halys from regions where other species of Halyomorpha are native (e.g., India - NIKAM \& More 2016 [corrected by SALINI et al. 2021 a] and Nigeria - BorISADE et al. 2017), suggest that a taxonomic revision and compilation of a reliable identification key to distinguish species of the genus are urgently needed. During the first steps of this revisional work, we noticed a strange discrepancy concerning the type species of the genus: according to MAYR (1864, 1866), the type species of Halyomorpha is, by monotypy, Halys timorensis Westwood, 1837 (currently considered a junior subjective synonym of $H$. picus) described from Timor Island (Lesser Sunda Islands). However, MAYR $(1864,1866)$ based his description of the new genus on material collected in southern China, an area currently known to host only $H$. halys (cf. RIDER 2006, VÉTEK et al. 2014). In this paper, we revise the original material examined by MAYR (1864, 1866) as well as the available syntypes of $H$. timorensis and $H$. halys, and provide the required nomenclatural changes.

\section{Material and methods}

Photographs were made partly using a Canon MP-E $65 \mathrm{~mm}$ macrolens attached to a Canon EOS 550D camera (Figs 1-3, 15-23) and partly with an AF-S Micro Nikkor $60 \mathrm{~mm} \mathrm{f} / 2.8 \mathrm{G}$ ED lens attached to a Nikon D90 camera (Figs 24-26). Final images were stacked from multiple layers using the Helicon Focus 5.1 Pro software. Uncoated specimens were examined by a Hitachi S-3700N environmental scanning electron microscope at the Department of Palaeontology, National Museum, Prague.

The following dimensions were measured in dorsal view: body length (from apex of mandibular plates to apex of membrane), head length (from apex of mandibular plates to anterior margin of pronotum), head width (including compound eyes), interocular width (between mesal margins of compound eyes), length of each antennomere, length of each labiomere, pronotum length (medially, from anterior to posterior margin of pronotum), pronotum width (maximum width between humeri), scutellum length (medially, from base to apex), scutellum width (maximum width between basal angles of scutellum), and abdomen width (maximum width across posterolateral angles of segment III). The measurements were subsequently standardized to provide absolute lengths. Morphological terminology follows Tsai et al. (2011), KMENT et al. (2019), ZHOU \& RÉDEI (2020) and SALINI \& KMENT (2021).

In quoting the labels of the material examined, a slash (/) is used to divide data on different rows of one label, a double slash (//) is used to divide the data on different labels, authors' comments are given in square brackets [ ], and the following abbreviations are used: $[\mathrm{hw}]=$ hand written, $[\mathrm{p}]=$ printed. Unless stated otherwise, the described labels are off-white.

Specimens deposited in the following museums were examined:
NHMW Naturhistorisches Museum, Vienna, Austria;
NHRS Naturhistoriska Riksmuseet, Stockholm, Sweden;
OXUM Oxford University Museum, Hope Entomological Collections, Oxford, United Kingdom;
RMNH Naturalis (former Nationaal Natuurhistorisch Museum), Leiden, the Netherlands;
ZMUC Zoological Museum, University of Copenhagen, Denmark.

\section{Results}

\section{Halyomorpha Mayr, 1864}

Halyomorpha Mayr, 1864: 911 (original description). Type species: Halys timorensis Westwood, 1837, by monotypy.

Halyomorpha: MAYR (1866): 47-50 (redescription, differential diagnosis); STÅL (1868a): 515 (key to genera); STÅL (1876): 57 (key to genera), 74-75 (key to species, catalog); ATKInson (1888): 23 (diagnosis); LETHIERRY \& SEVERIN (1893): 117-118, 267 (World catalog); DisTANT (1902): 148 (key to genera), 152 (diagnosis); OSHANIN (1906): 106 (Palearctic catalog); Bergroth (1908): 161 (catalog); KirKaldy (1909): 49-50 (World catalog); OSHANIN (1912): 12 (Palearctic cata$\log$ ); JEANNEL (1913): 61, 67-68 (diagnosis, key and catalog of African species); BerGRoth (1921): 4-8 (systematics, possible placement in Halyini); HoffMANN (1932): 7 (checklist); TANG (1935): 313-314 (Chinese catalog); BEIER (1938): 2187 (list); CACHAN (1952): 397, 402 (key, redescription; included in Carpocorini); VILLIERs (1952): 68 (diagnosis); Stichel (1961): 752 (Palearctic catalog); Stichel 
(1962): 233 (Palearctic catalog); Ahmad et al. (1974): 22, 77 (key to genera); HsiaO et al. (1977): 102 (key to genera); MEDLER (1980): 125 (Nigeria, checklist); AHMAD (1981): 21 (key to genera); LINNAVUORI (1982): 114-118 (key to genera, diagnosis, species-groups and key to Afrotropical species); ABBASI (1986): 28 (key to genera), 65-66 (diagnosis); AHMAD \& ZAIDI (1989): 238-239 (redescription, key to Indo-Pakistan species), 248-253 (phylogenetic relationships); ZAIDI et al. (1990): 41-47 (phenetics); HASAN (1993): 209-210 (redescription, key to species of Malayan subregion); LIN \& ZHANG (1993): 119 (key to genera); ZAIDI \& SHAUKAT (1993): 60-65 (phenetics); Chakraborty \& Ghosh (1999): 392 (list), 397 (key to genera); GaDAlla (2004): 49 (diagnosis); LiU \& WANG (2004): 183 (key to genera); WANG \& LIU (2005): 285 (key to genera); RIDER (2006): 261 (Palearctic catalog); BISWAS \& BAL (2007): 313 (key to genera); RIDER (2012): 330 (key to genera); SWANSON (2012): 297 (list); AuKEMA et al. (2013): 448 (Palearctic catalog); SALINI \& ViraKtAMATH (2015): 12, 16-17 (key to genera, checklist, India); RIDER et al. (2018): 76, 100, 105-106, 134, 197, Fig. 2.28 (systematic placement); RocACusachs \& Jung (2020): 37, 46 (in key, fauna of South Korea); SALINI (2020): 129 (key).

Halymorpha [incorrect subsequent spelling]: NonNAIZAB (1986): 117 (key to genera), 206 (diagnosis)

Cappaea [misidentification]: Medler (1980): 124 (Nigeria, checklist).

Material examined. Halyomorpha halys: $2 \curvearrowright 1 q$, 'Novara Exp. / China. [hw] // timorensis [hw] / det. Mayr [p, black line submarginally] // SPECIMEN USED / FOR DESCRIPTION / OF HALYOMORPHA / MAYR, 1864 [p] // HALYOMORPHA / HALYS / (Stål, 1855) / det. P. KMENT 2021 [p]' (NHMW). Body lengths: §ో $12.80 \mathrm{~mm}$ (Fig. 1) and $13.17 \mathrm{~mm}$, $14.92 \mathrm{~mm}$.

Halyomorpha picus: 1 ( (Fig. 2), 'Novara Exp. / China. [hw] // timorensis [hw] / det. Mayr [p, black line submarginally] // SPECIMEN USED / FOR DESCRIPTION / OF HALYOMORPHA / MAYR, 1864 [p] // HALYOMORPHA / PICUS / (Fabricius, 1794) / det. P. KMENT 2021 [p]' (NHMW). Body length: $14.63 \mathrm{~mm}$.

Nomenclature. The exact date of publication of the paper containing the original description of the genus Halyomorpha is uncertain. The manuscript was presented by G. L. Mayr at the meeting (Sitzung) of the Kaiserlich-Königliche Zoologisch-Botanische Gesellschaft in Wien [= Imperial and Royal Zoological and Botanical Society in Vienna] on the 7th of December 1864 (cf. MAYR 1864: 903). The receipt of a published preprint of the article was mentioned in the record of the meeting of the Matematisch-Naturwissenschaftliche Classe der Kaiserlichen Akademie der Wissenschaften [= Imperial Academy of Sciences, Branch of Mathematics and Natural Sciences] on the 9th of February 1865 (cf. Sitzungsberichte der Matematisch-Naturwissenschaftliche Classe der Kaiserlichen Akademie der Wissenschaften, vol. 51, issue 2, p. 135). The first traceable record of the entire published volume (vol. 14, for 1864) of Verhandlungen der Kaiserlich-Königlichen Zoologisch-Botanischen Gesellschaft in Wien, consisting of three issues (1-2, 3 and 4), mentioned it with the date of 23 February 1865 (cf. vol. 15, p. 17 of the same journal); the Allgemeine Bibliographie für Deutschland recorded it on p. 68 of issue 9 of its 1865 volume, published on 2 March 1865. Mayr's article (contained in issue 4) was certainly published and distributed as a preprint after 7 December 1864 but before 9 February 1865 , possibly only in early 1865. Because a publication in late December 1864 cannot be excluded, the date printed on the front page of the volume (1864) is, however, accepted. The correct publication date of MAYR (1866) was discussed by HigGins (1963).
Halyomorpha was established for a single included species (i.e., type species by monotypy), cited as 'Halyomorpha timorensis Hope' (MAYR 1864); however, this taxon name must be attributed to J. O. Westwood (see KIRKALDY 1907). Subsequently, MAYR (1866) provided a detailed redescription of Halyomorpha and compared it with Pentatoma Olivier, 1789 and Oncocoris Mayr, 1866; he listed the single included species as 'Halys timorensis Westwood'. The original description and subsequent redescription of the genus and the included species (MAYR $1864,1866)$ were all said to be based on specimens from Hongkong and Shanghai, China. STÅL (1876) listed both Halyomorpha timorensis and H. halys (the latter species described from China) as junior subjective synonyms of $H$. picus. His taxonomic framework was almost universally accepted for the following one hundred years, and $H$. picus was accordingly considered as a species widely distributed in eastern and southeastern Asia (e.g., DisTANT 1902, KirKaldy 1909, Hsiao \& Zheng 1977). However, starting with ESAKI (1955: 165), most Japanese authors of the 20th century distinguished the Japanese populations of Halyomorpha as a separate species, H. brevis Walker, 1867, originally described also from Hongkong (WALKER 1867a). Josifov \& KeRZHNER (1978) examined representative material of Halyomorpha specimens from the Palearctic East Asia (Japan, Korea and east China), and concluded that they belong to a single species, distinct from $H$. picus distributed in the Oriental Region. Accordingly, they resurrected $H$. halys as the oldest available name for the East Palearctic species, but they accepted H. timorensis as a junior synonym of $H$. picus. All subsequent authors accepted $H$. picus as the type species of Halyomorpha (Nonnaizab 1986, Ahmad \& Zaidi 1989, Hasan 1993, GADALLA 2004, RIDER 2006), despite the fact that MAYR $(1864,1866)$ purportedly based the generic description on specimens from southeast China, where only $H$. halys is known to occur (see HsiaO \& ZHENG 1977, as H. picus; JOSIFOV \& KERZHNER 1978; RIDER et al. 2002; RIDER 2006; VÉTEK et al. 2014; HAMILTON et al. 2018).

To elucidate the contradiction concerning the identity of the type species of Halyomorpha, we borrowed the voucher specimens from Mayr's collection, now housed in the Naturhistorishes Museum in Vienna. Due to the courtesy of Herbert Zettel, we examined four specimens bearing the original locality labels of Novara Expedition and identification labels by Mayr. Among them we identified two males and one female of $H$. halys (male and female external genitalia corresponding with illustrations in VÉTEK et al. 2014 and SALINI et al. 2021a) and one male of $H$. picus (external male genitalia corresponding with SALINI et al. 2021a, KMENT et al. 2021, and a male syntype of $H$. picus in ZMUC - P. Kment, pers. observ.). Concerning the presence of $H$. picus among the examined material from 'China', we were convinced about the mislabelling of the specimen, originating most probably from Ceylon [= Sri Lanka] or Madras [= Chennai, India], areas that were also visited and sampled during the Novara Expedition (SCHERZER 1861a,b). We further examined the only avail- 


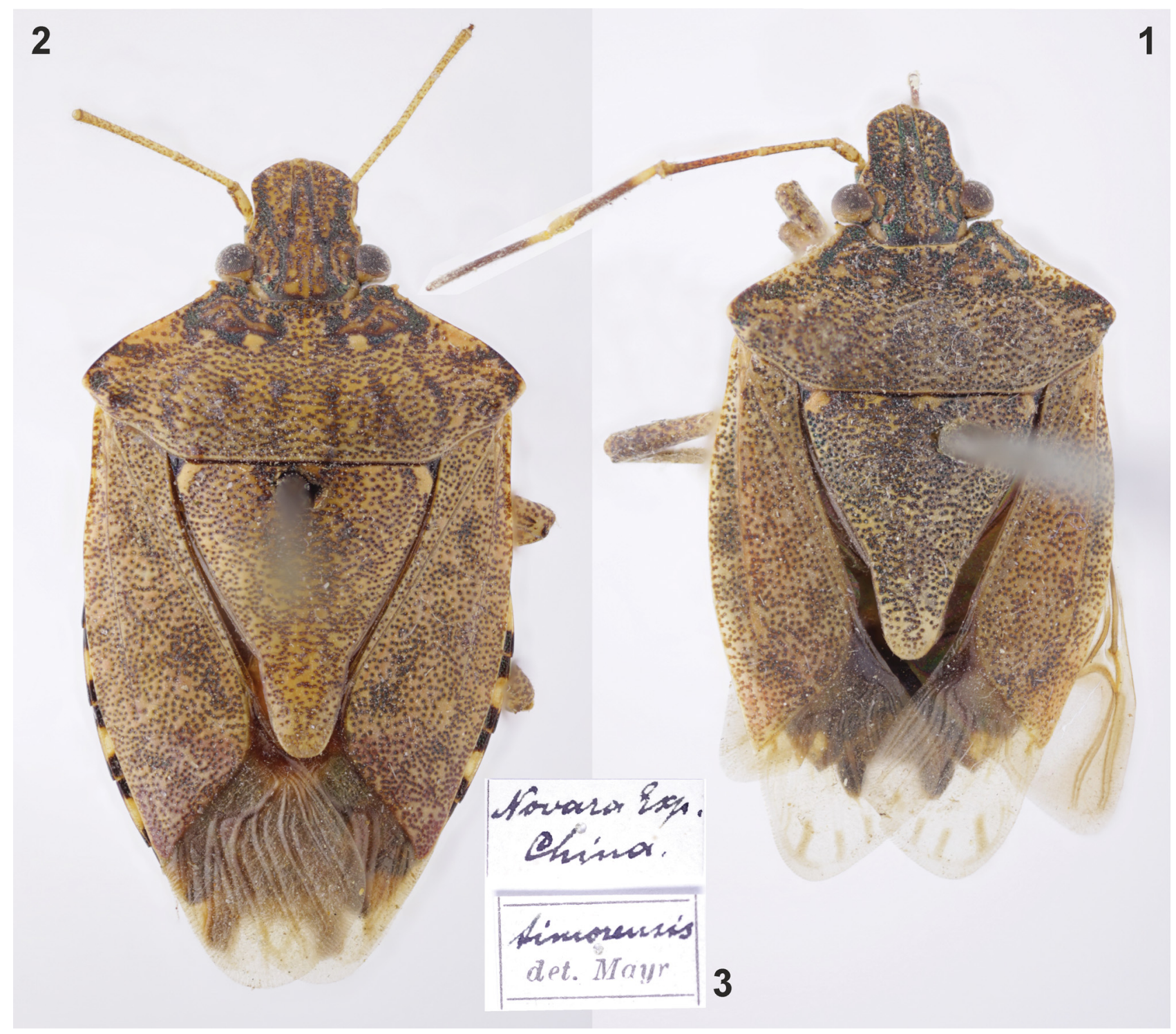

Figs 1-3. Specimens of Halyomorpha Mayr, 1864 from Mayr collection (NHMW): 1 - Halyomorpha halys (Stål, 1855), male (body length 12.80 mm); 2 - Halyomorpha picus (Fabricius, 1794), male (14.63 mm); 3 - labels. Orig. P. Kment.

able syntype of Halys timorensis held in the collection of the Oxford University Museum. Based on its examination we accept $H$. timorensis as a valid species distinct from $H$. picus (see below).

These discoveries result in a rather unusual case of double misidentification of the type species of Halyomorpha. In such a situation, Article 70.3 of the ICZN (1999) applies, and we are supposed to select, and thereby fix as type species, the species that will best serve stability and universality of zoological nomenclature, either i) the nominal species previously cited as type species (i.e., Halys timorensis Westwood, 1837, Art. 70.3.1) or ii) the taxonomic species actually involved in the misidentification (i.e., either Cimex picus Fabricius, 1794 or Pentatoma halys Stål, 1855, Art. 70.3.2). As H. timorensis is a poorly known species with male characters unknown, and there is no doubt that the description of Halyomorpha (MAYR 1864, 1866) was based on a study of other species, we consider the first possibility as inadvisable. Of the two remaining taxa, we prefer to choose $H$. halys, the species native in Hongkong and Shanghai area and currently by far the best known and intensively studied species of Halyomorpha (cf. Hamilton et al. 2018). Therefore, we fix here Pentatoma halys Stål, 1855 [= Halys timorensis (non Westwood, 1837): MAYR (1864) (partim), misidentification] as the type species of Halyomorpha Mayr, 1864 acting as first revisers according to the Article 70.3 of the ICZN (1999).

\section{Halyomorpha timorensis (Westwood, 1837), stat. restit. (Figs 15-20, 22)}

Halys timorensis Westwood, 1837: 6, 22 (original description). Cappcea timorensis: STÅL (1865): 170 (new combination).

Halyomorpha timorensis: STÅL (1876): 75 (as junior subjective synonym of $H$. picus).

The following bibliographic records of H. timorensis are based on misidentifications and pertain to other species:

Pentatoma timorensis [misidentification of H. picus]: Dallas (1851): 242 (new combination, distribution); HERRICH-SCHÄFFER (1853): 



Figs 4-9. Halyomorpha halys (Stål, 1855), male genitalia of the specimen from Mayr collection (NHMW). 4-8 - genital capsule (4 - posterior view, magnification $55 \times ; 5$ - dorsoposterior view, $47 \times ; 6$ - ventral view, $35 \times ; 7$ - dorsal view, $37 \times ; 8$ - lateral view, $47 \times)$; 9 - paramere in posterior mediolateral view $(170 \times)$. Abbreviations: pa - parameres, plp - posterolateral lobes of genital capsule. Scale bars: $4-8-0.5 \mathrm{~mm}, 9-0.2 \mathrm{~mm}$. Orig. P. Kment. 

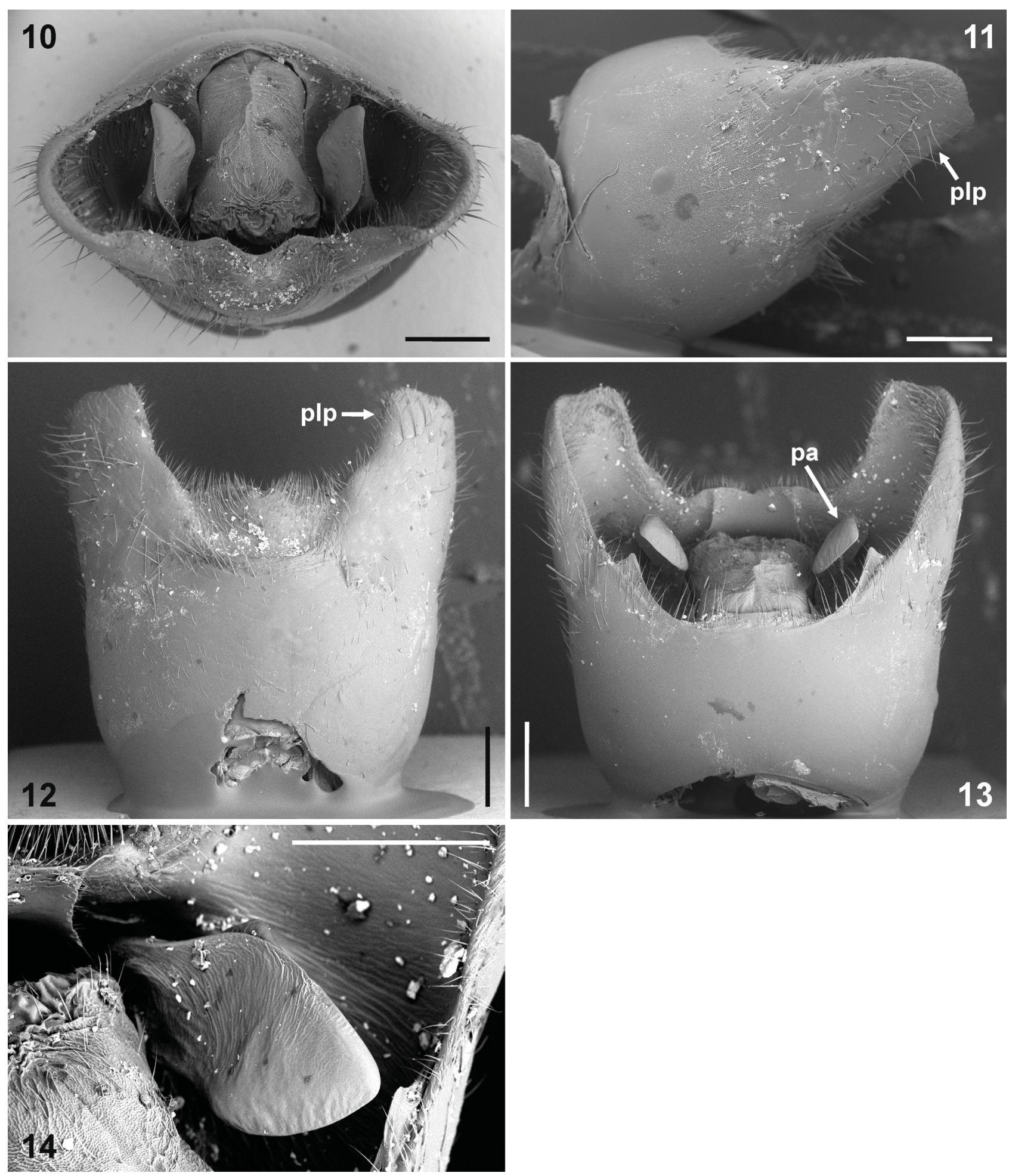

Figs 10-14. Halyomorpha picus (Fabricius, 1794), male genitalia of the specimen from Mayr collection (NHMW). 10-13 - genital capsule (10 - posterior view, magnification $42 \times ; 11$ - lateral view, $42 \times ; 12$ - ventral view, $30 \times ; 13$ - dorsal view, $32 \times) ; 14$ - paramere in posterior mediolateral view $(100 \times)$. Abbreviations: pa - parameres, plp - posterolateral lobes of genital capsule. Scale bars: $0.5 \mathrm{~mm}$. Orig. P. Kment. 


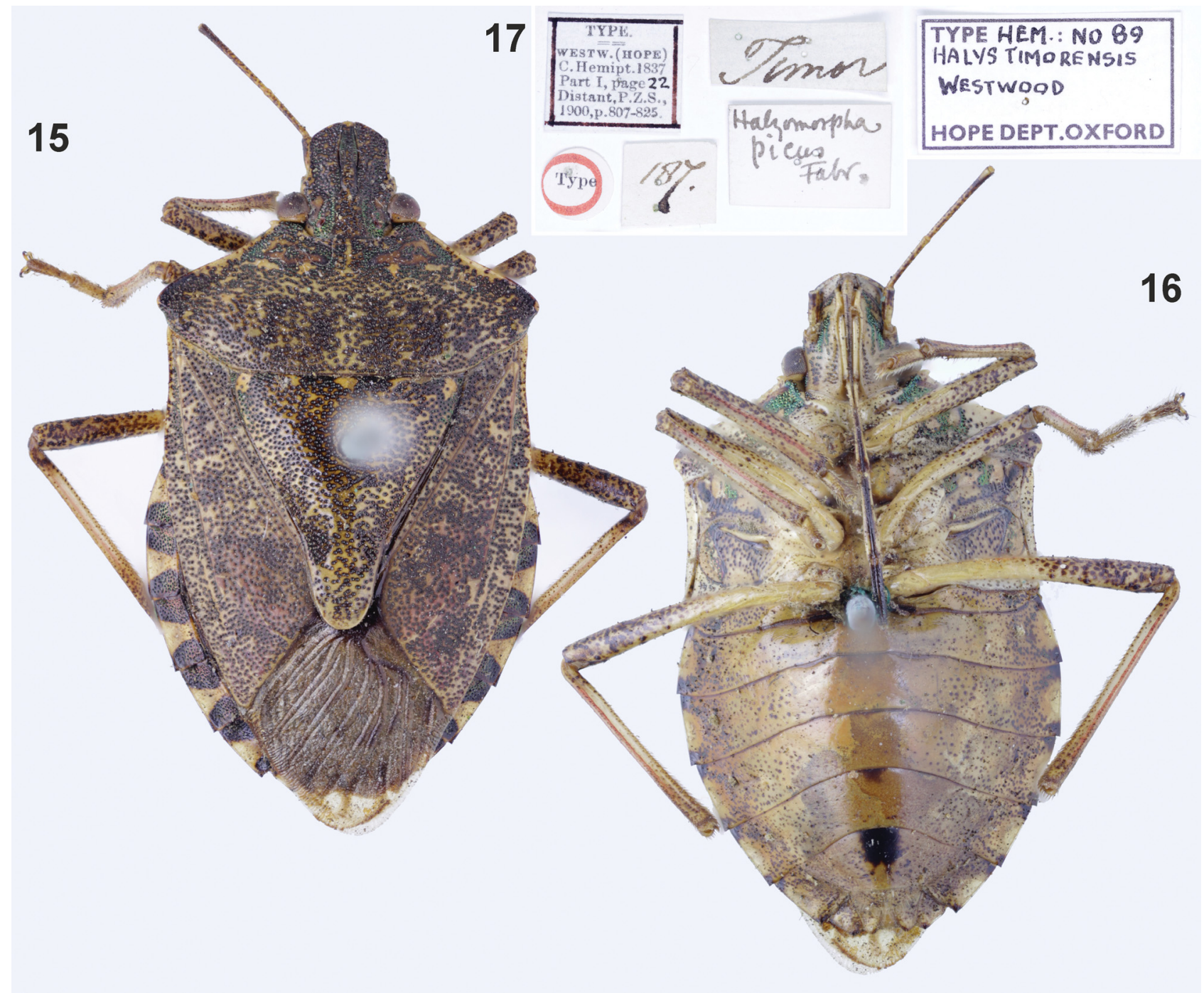

Figs 15-17. Halys timorensis Westwood, 1837, female syntype (OXUM) (body length $15.4 \mathrm{~mm}$ ): 15 - dorsal view, 16 - ventral view, 17 - labels. Orig. P. Kment.

159 (list, distribution); DoHRn (1859): 15 (catalog, distribution); MotsCHULSKY (1863): 74 (checklist).

Pentatoma Timorensensis [incorrect subsequent spelling; misidentification of H. picus]: WALKER (1859): 292 (list).

Halyomorpha timorensis [misidentification of $H$. halys and $H$. picus]: MAYR (1864): 912 (new combination, distribution); MAYR (1866): 50, pl. 1: figs 7a,b (redescription, figures, distribution).

Halyomorpha timorensis [misidentification of H. picus]: WALKER (1867b): 299 (distribution).

Halyomorpha timorensis [misidentification of $H$. halys]: SIGNORET (1881): 46 (list).

Material examined. SynTYPE: $\circ$ (Figs 15-16), 'Timor [hw] // 187. [hw] // Halyomorpha / picus / Fabr. [hw] // Type [p, white circle with red margin] // TYPE. / = = / WESTW. (HOPE) / C. Hemipt. 1837 / Part I, page [p] 22 [hw] / Distant,P.Z.S., / 1900,p.807-825. [p, black frame submarginally] // TYPE [p] HEM.: NO 89 / HALYS TIMORENSIS / WESTWOOD [hw] // HOPE DEPT.OXFORD [p, black frame submarginally] // SYNTYPE / HALYOMORPHA / TIMORENSIS / (Westwood, 1839) / det. P. KMENT 2021 [p. red label]' (OXUM). Specimen pinned through scutellum, missing the following parts: right antennomeres IIaIV, left antennomeres III-IV, right protarsomeres II-III, left protarsomere III, right mesotarsomeres II-III, and all metatarsomeres.
Redescription. Colour, integument and vestiture (Figs 15-16). Head above, pronotum, scutellum, clavus and exocorium yellowish, endocorium partly brownish, with variegated pattern formed by more or less densely distributed black punctures (Fig. 15), sometimes so dense, and with dark interspaces, to form black-appearing spots (especially on midlength of clypeus, submarginally on anterolateral angles of pronotum, on humeral angles, and at frenal incisions laterally on scutellum); yellowish interspaces between punctures in some places swollen to form callosities, most prominent ones on calli and behind them, on scutellum one in each anterolateral corner, one anteromesially, and in apical portion of scutellum (Fig. 15). Connexival segments with about anterior and posterior third black with purple metallic shine, middle third and posterolateral margin narrowly yellowish, with concolorous punctures (Fig. 15). Membrane brownish, translucent, basal angle dark brown. Antennae yellowish with small brown spots, on scape partly coalescent. 
Ventral side of body yellowish with scattered minute brown spots (Fig. 16). Head and thorax ventrally with large, deep punctures, often with green or purple metallic shimmer, forming larger irregular spots around antenniferous tubercles and on pro-, meso-, and metapleuron, especially on humeral angles. Labiomere I yellowish, II and III yellowish with black stripe ventrally, IV black. Abdominal venter, including laterotergites VIII and IX and valvifers VIII, with scattered brown punctures, becoming denser towards lateral margins; ventrite VI with small and VII with large dark brown spot anteromesally (Fig. 16); spiracles surrounded by black ring; ventrites laterally with small dark brown spots in anterior and lateral angles and semicircular spot of translucent cuticle in the middle, the latter being surrounded by yellowish C-shaped spot nearly devoid of punctures (Fig. 16). Legs yellowish, femora and tibiae with scattered brown spots (those becoming denser towards apex), anterior ridge on dorsal surface of tibiae emarginated by reddish line (Fig. 16).

Scutellum, connexivum, and ventral side of the body shining, head dorsally and pronotum submatte, calli on pronotum, corium, and evaporatorium of the metathoracic scent efferent system matte. Body glabrous, femora, tibiae and external female genitalia with short pale pilosity.

Structure very similar to $H$. halys and $H$. picus. Head anteriorly widely parabolic, apex of clypeus slightly surpassing apices of mandibular plates; lateral margins parallel in middle (Fig. 15), insinuate in front of eyes, antenniferous tubercles visible from above. Anterolateral margins of pronotum carinate, slightly concave in anterior half; humeral angles subrectangular, narrowly rounded (Fig. 15). Scape reaching rounded portion of head margin (Fig. 15), length of antennomeres: IIb $>$ IIa $>$ I. Labium reaching ventrite III (Fig. 16). Peritreme of metathoracic scent gland ruga-shaped, pointed apically (Fig. 18). Dorsal surface of all tibiae flattened, laterally carinate. Abdomen slightly wider than pronotum across humeral angles.

External female genitalia (Figs 19-20, 22) with posterior margins of valvifers VIII nearly straight (Fig. 20); laterotergites IX in apical half parabolic, narrowly rounded (Fig. 20); posterior margins of laterotergites VIII obtusangulate, each angle provided with a small denticle (Fig. 20: yellow arrows, 22: red arrows).

Measurements (mm). Body length 15.23; head: length 3.04 , width 3.14, interocular width 1.72; lengths of antennomeres: scape (I) 0.83 , basipedicellite (IIa) 1.47, distipedicellite (IIb) 2.21, basiflagellum (III) and distiflagellum (IV) missing; lengths of labiomeres: I -1.37 , II -2.40 , III - 1.81, IV - 1.72; pronotum: length 3.09 , width 8.29 ; scutellum: length 5.54, width 5.15; abdomen: width 8.63. Differential diagnosis. The examined specimen fits in its structure, coloration and measurements within the known variability of $H$. halys and $H$. picus. The external female genitalia of $H$. timorensis resemble those of $H$. halys in having laterotergites IX in apical half parabolic, narrowly rounded (Fig. 20) and posterior margins of laterotergites VIII obtusangulate, each angle provided with a small black denticle (Fig. 20: yellow arrows, 22: red arrows; VÉTEK et al. 2014: fig. 15; SALINI et al. 2021a: fig. 1g). In
H. picus, the laterotergites IX are less parabolic and more broadly rounded, and the posterior margins of laterotergites VIII are nearly regularly rounded, apically blackened but without a denticle (KMENT et al. 2021: fig. 6; SALINI et al. 2021a: fig. 1f).

Distribution. Lesser Sunda Islands: Timor (WESTWOOD 1837).

Comments. In the original description of Halys timorensis, Westwood (1837) gave only a single measurement, but provided no other indication concerning the number of examined specimen(s). We were able to examine a single female syntype located in OXUM. As identification of females of this species complex is currently problematic, we refrain from designating the available female syntype as lectotype, leaving more opportunity for a later selection of a potentially more suitable specimen.

The examination of the syntype revealed that $H$. timorensis is very similar in coloration, structure and measurements to $H$. halys and $H$. picus, except the characters of the external female genitalia. The shape of the laterotergites VIII and IX of $H$. timorensis matches that of $H$. halys, but it clearly differs from $H$. picus and therefore $H$. timorensis must be removed from synonymy of the latter species. Further, our examination of the available male specimens of Halyomorpha from Indonesia and the Philippines has not revealed a single specimen of $H$. halys, but that area is inhabited by several other habitually similar species, described or not. In this situation we refrain from proposing $H$. timorensis stat. restit. as a junior synonym of $H$. halys and prefer to treat it as a dubious but valid species, until corresponding male specimens from Timor Island can be examined.

\section{Halyomorpha halys (Stål, 1855)}

(Figs 1, 24-26)

Pentatoma halys Stål, 1855: 182 (original description). For a list of synonyms see RIDER (2006) and the checklist below.

Type material examined. SyntyPe: $q$ (Figs 24-26), 'China. [p] // Hamb [hw] // + [p] // halys / Stål / Typ. [hw] // Typus [p, red, with black frame] // 182 [p] / 69 [hw in blue]' (NHRS). Specimen pinned through scutellum, left metatarsus missing, right antenna broken between basiand distiflagellites but repaired by previous worker using glue (NHRS). SynTYPE: $q$, 'China. [p] // Hamb [hw] // $q[\mathrm{p}]$ '. Specimen pinned through scutellum, left antenna and left protarsomeres II-III missing (NHRS). Additional specimens examined. 1 , ,Hongkong [hw] // Stål. [p] // Typ. [p] // Cappaea / halys Stål. [hw]' (NHRS). 1 +, 'Japonia [hw] // Mus. / Leyden [hw] // Pentatoma / dalpadoides / Voll. Typ. [hw] // Paratypus [p, red, with black frame]' (NHRS).

Comments. As H. halys is fixed in this paper as the type species of Halyomorpha, its identity is of particular interest. The species was described based on an unspecified number of specimens (syntypes) from 'China'; a subsequent paper (STÅL 1856) stated that the specimens were provided by 'Dom. [= Mr.] Hamberg'. Two females from the same lot of specimens, matching the original description (STÅL 1855) and information subsequently provided by the same author (STÅL 1856) and certainly belonging to the type material of Pentatoma halys, have been located in NHRS; to facilitate a revision of the genus, the one in better condition is illustrated here (Figs 24-26). Both specimens are consistent with the identification of 
this species by recent authors (e.g., JOSIFOV \& KERZHNER 1978 or VÉTEK et al. 2014).

Two additional females, one from 'Hongkong' and one from 'Japonia' [= Japan], were labelled as types and pinned together with the above listed two syntypes of $H$. halys, but as they are not from the type locality of $H$. halys as listed by STÅL $(1855,1856)$, they are considered as having no type status. One of them is provided with a handwritten label 'Pentatoma dalpadoides Voll[enhoven]', which is apparently an unpublished name; Gynenica dalpadoides Vollenhoven, 1867 (currently Platynopus dalpadoides) is an unrelated species belonging to Asopinae (THOMAS 1994), its type material is deposited in RMNH and has been seen by us (D. Rédei, pers. observ.).
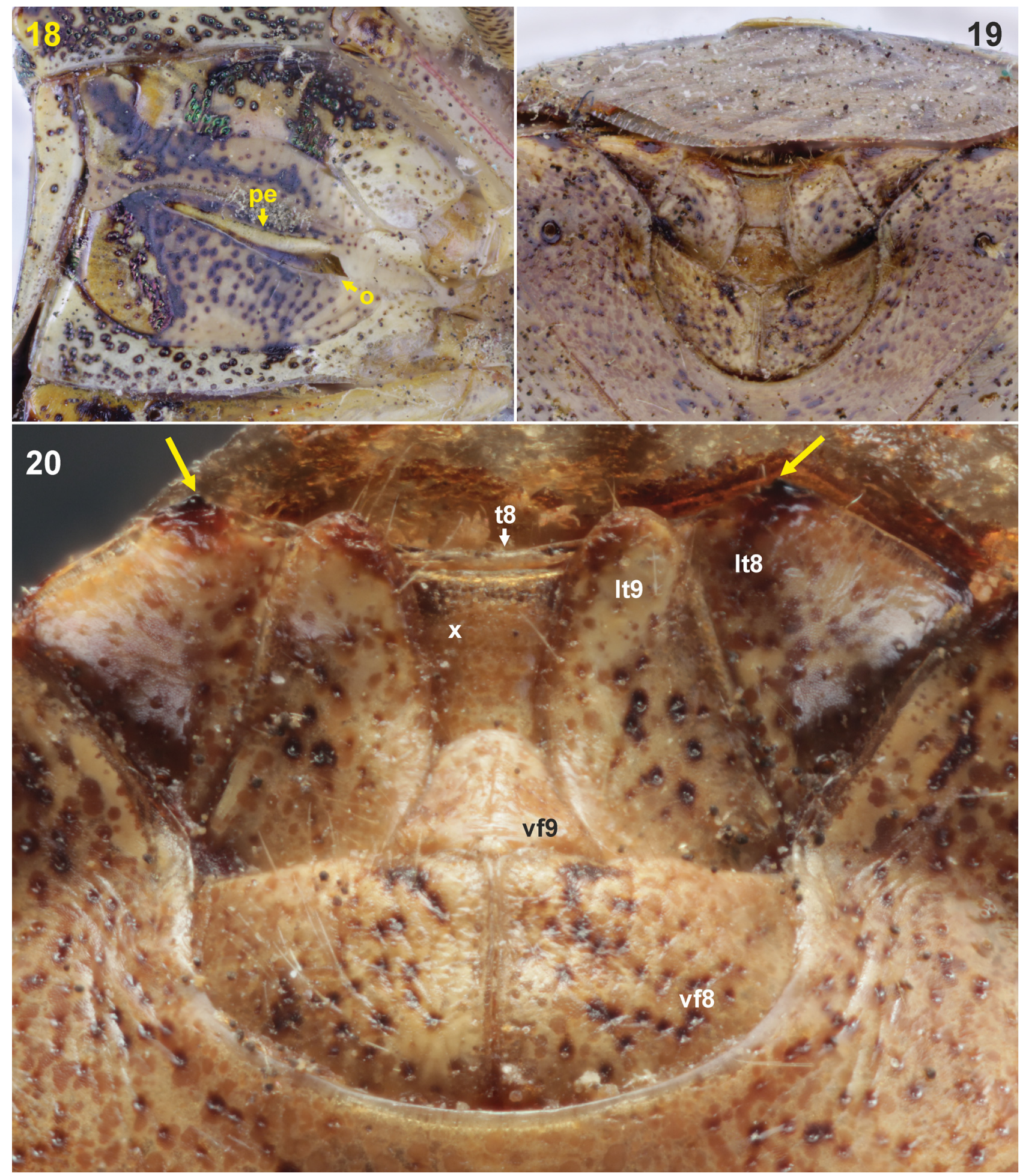

Figs 18-20. Halyomorpha timorensis (Westwood, 1837), female syntype: 18 - external scent efferent system of the metathoracic scent gland; 19-20 external genitalia (19- posterior view, 20 - ventral view, angle on posterior margin of 1 t8 shown by yellow arrows). Abbreviations: 1t8-9- laterotergites $8-9, \mathrm{o}-$ ostiole, pe - peritreme in form of peritremal ruga, $\mathrm{t} 8$ - tergite 8 , vf8-9 - valvifers $8-9, \mathrm{x}-$ segment X. Orig. P. Kment. 


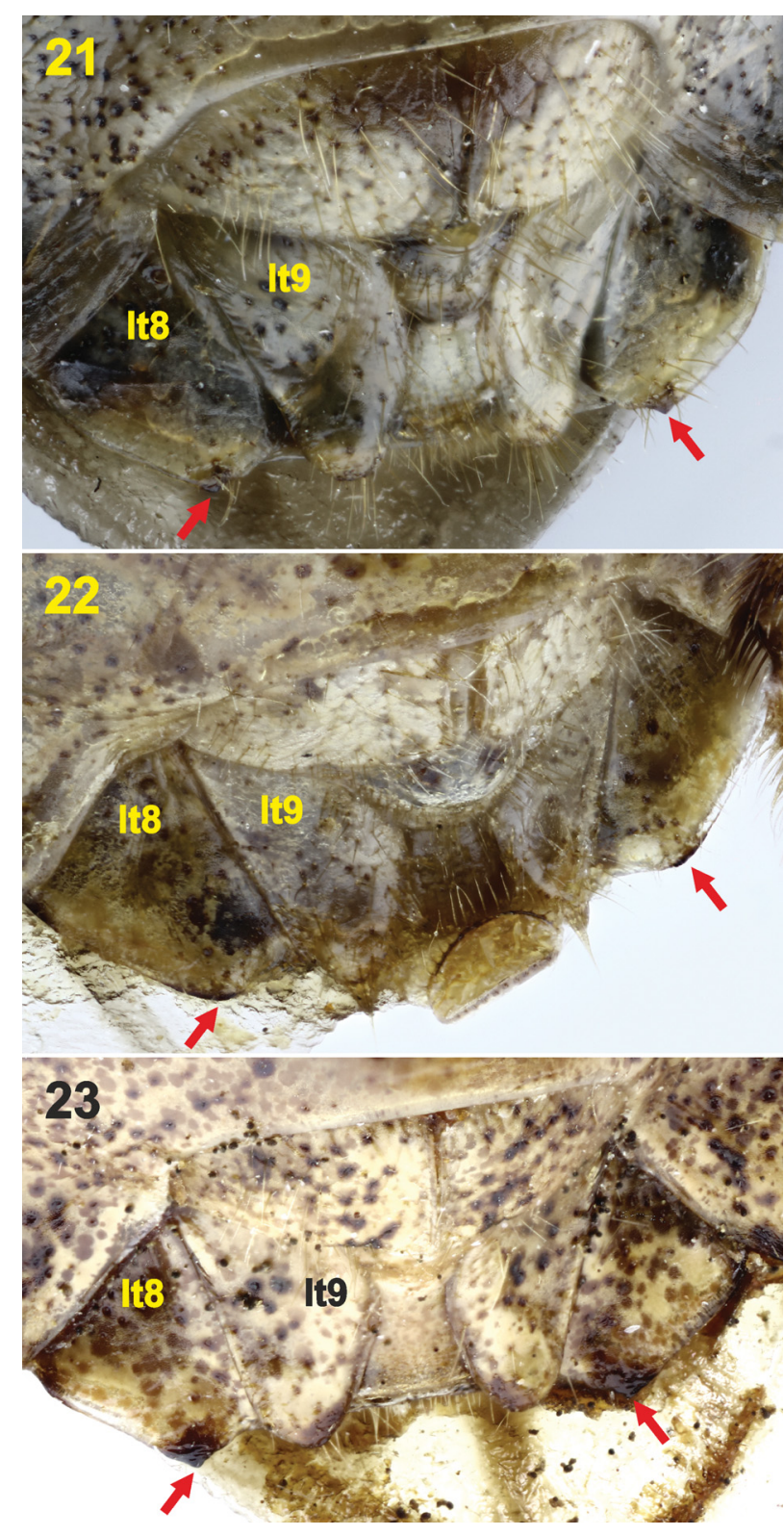

Figs 21-23. Halyomorpha Mayr, 1866, external female genitalia in ventrolateral view (angle on posterior margin of $1 \mathrm{t} 8$ shown by red arrows): $21-H$. halys (Stål, 1855), Czech Republic: Praha, botanical garden of the Charles University; 22 - H. picus (Fabricius, 1794), Pakistan: Islamabad, National Institute of Health colony; $23-$ H. timorensis (Westwood, 1837), syntype. Abbreviations: 1t8-9- laterotergites 8-9. Orig. P. Kment.

\section{List of species currently included in Halyomorpha}

Halyomorpha angusticeps Bergroth, 1914: 451 [tropical Africa] H. angustisecta Linnavuori, 1982: 115, 117 [Ivory Coast]

H. annulicornis (Signoret, 1858): Pentatoma annulicornis Signoret, 1858 in FAIRMAIRE \& SignORET (1858: 284) [tropical Africa]

H. bimaculata Bergroth, 1892: 160 [tropical Africa]

H. canalana Distant, 1914: 374, pl. XII: fig. 7 [New Caledonia]

H. capeneri Leston, 1952: 513 [South Africa]

H. carmona Linnavuori, 1982: 115, 116 [Angola]

H. collocata (Walker, 1867): Dalpada collocata Walker, 1867a: 221 (syn. with $H$. picus suggested by DisTANT (1893: 393), treated as valid by HaSAN 1993: 211) [Indonesia: Java, Sumatra]

H. distanti Jeannel, 1913: 71 [tropical Africa, Yemen]

H. fletcheri Distant, 1918: 129 [Myanmar]
H. guttula (Ellenrieder, 1862): Halys guttula Ellenrieder, 1862: 144, pl. II: fig. 12. [Indonesia: Sumatra]

H. halys (Stål, 1855): Pentatoma halys Stål, 1855: 182 (syn. with H. picus by STÅL 1876: 75, restored as valid species by JOSIFOV \& KERZHNER 1978: 172) [native: China, Japan, Korea, Taiwan, Vietnam; introduced: West Palearctic: Europe, Transcaucasia, Turkey, Kazakhstan, North Africa; Nearctic: Canada, USA; Neotropical: Puerto Rico, Chile; Oceania: Guam; Afrotropical: ? Nigeria].

= Poecilometis mistus Uhler, 1860: 223 (syn. with H. picus by DisTant 1893: 394, with $H$. halys by Josifov \& KerZHNER 1978: 172).

= Dalpada brevis Walker, 1867a: 226 (syn. with H. picus by DisTANT 1893: 394, with $H$. halys by Josifov \& KERZHNER 1978: 172).

= Dalpada remota Walker, 1867a: 227 (syn. with $H$. picus by DISTANT 1880: 201 and 1893: 394, with H. halys by Josifov \& KerZHNER 1978: 172).

H. hasani Rider \& Rolston, 1995: 847 (new substitute name for $H$. punctata Hasan, 1993) [Malaysia: Malaya]

= Halyomorpha punctata Hasan, 1993: 214 (junior primary homonym of $H$. punctata Cachan, 1952)

H. javanica Hasan, 1993: 212 [Indonesia: Java]

H. lata Breddin, 1899: 162, fig. 2 [Indonesia: Lesser Sunda Islands: Lombok]

H. leopoldi Schouteden, 1933: 50 [Indonesia: Kalimantan]

H. longiceps Breddin, 1900a: 143, pl. IX: fig. 3 [Indonesia: Maluku Islands: Ternate]

H. malleata (Distant, 1890): Atelocera malleata Distant, 1890: LIII, LV [Democratic Republic of the Congo]

H. mayumbeensis Villiers, 1967: 1791 [Republic of the Congo]

H. murrea Distant, 1887: 344, pl. XII: fig. 5 [India]

H. ornativentris Breddin, 1900b: 296 [Indonesia: Borneo, Sumatra]

H. philippina Black, 1968: 567 [Philippines: Balabac]

H. picoides Linnavuori, 1975: 87 [tropical Africa]

H. picticornis Bergroth, 1915: 171 [India]

H. picus (Fabricius, 1794): Cimex Picus Fabricius, 1794: 115 [India, Pakistan, Sri Lanka, ? SE Asia]

= Cimex marmoreus Fabricius, 1798: 534 (syn. STÅL 1868b: 24)

= Cimex cinnamomeus Wolff, 1802: 99 (syn. STÅL 1868b: 24)

= Pentatoma trivialis Dohrn, 1860: 400 (syn. ATKINSON 1888: 23)

$?=$ Dalpada proxima Walker, 1867a: 227 (syn. DisTANT 1893: 394; the synonymy requires confirmation)

= Halyomorpha punjabensis Ahmad \& Kamaluddin, 1977: 72 (syn. KMENT et al. 2021: 431, 434)

= Halyomorpha azhari Ahmad \& Zaidi, 1989: 239, 240 (syn. KMENT et al. 2021: 431, 434)

H. punctata Cachan, 1952: 402, pl. XIII: fig. 6 [Comoros Islands]

H. reflexa (Signoret, 1858): Pentatoma reflexa Signoret, 1858 in FAIRMAIRE \& SigNORET (1858: 284) [tropical Africa]

H. rugosa Schouteden, 1913: 190 [tropical Africa]

H. schoutedeni Bergroth, 1913: 237 [Central African Republic]

H. scutellata Distant, 1879: 51 [India]

H. seyidiensis Jeannel, 1913: 67, 69, pl. II: fig. 20 [Kenya]

H. sinuata Hasan, 1993: 210 [Malaysia: Sabah]

H. timorensis (Westwood, 1837) stat. restit.: Halys timorensis Westwood,

1837: 22 [Lesser Sunda Islands: Timor]

H. viridescens (Walker, 1867): Atelocera viridiscens [sic!] Walker, 1867a: 215 [tropical Africa]

= Pentatoma (Cappaea) praetoria Gerstaecker, 1892: 46 (syn. JEANNEL 1913: 70)

= Halyomorpha erlangeri Schouteden, 1905: 12 (syn. JEANNEL 1913: 70 (with question mark), BERGROTH 1921: 7)

= Halyomorpha magnifica Bergroth, 1921: 6 (syn. LeSTON 1955: 702)

H. viridinigra Breddin, 1901: 11, 43 [Indonesia: Sulawesi]

H. yasumatsui Abbasi \& Ahmad, 1974: 72 [Bangladesh]

\section{Discussion}

This contribution, along with the recent paper by KMENT et al. (2021) synonymizing two poorly described species from Pakistan, represents the first step towards a revision of Halyomorpha. Further taxonomic and nomenclatural 


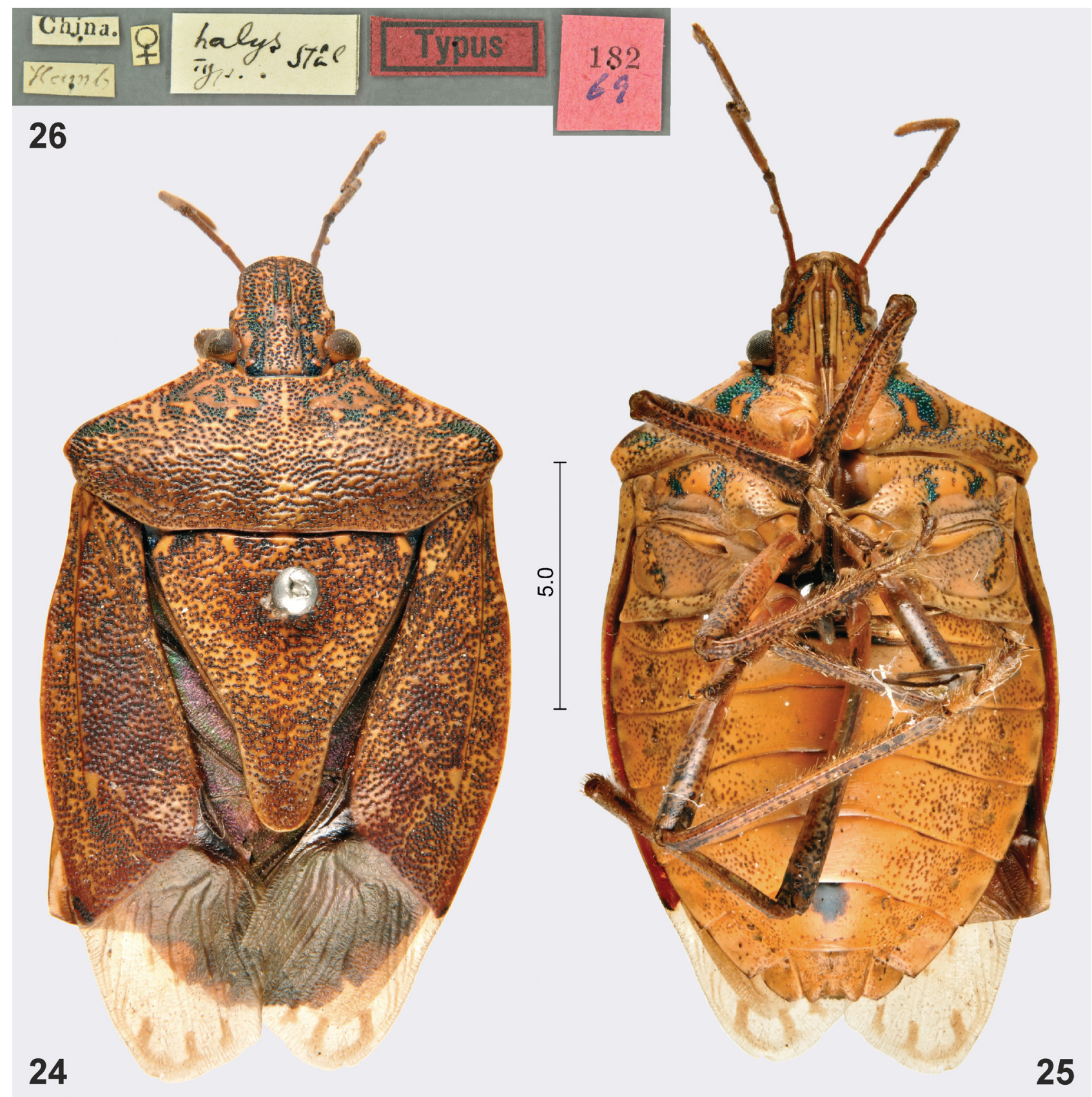

Figs 24-26. Pentatoma halys Stål, 1855, female syntype (NHRS): 24 - dorsal view, 25 - ventral view, 26 - labels. Scale bar in mm. Orig. D. Rédei.

problems have already been detected and will be treated in subsequent papers, including a test of the monophyly of Halyomorpha in its present sense and reconsideration of the identity of many of the included species, as well as descriptions of new ones. However, as the invasive $H$. halys became one of the most intensively studied species of true bugs in the last two decades, we would like to note at least one major problem which may negatively influence its research. It is necessary to keep in mind that $H$. halys belongs to a group of habitually similar species one could identify with certainty only by examination of their male genitalia, especially the structure of the genital capsule and paramere. Of this group, only the male genitalia of three species have been adequately described: $H$. halys (VÉTEK et al. 2014, SALINI et al. 2021a, this paper), H. picus
(KMENT et al. 2021, SALINI et al. 2021a, this paper), and $H$. yasumatsui (ABBASI \& AHMAD 1974); the remaining ones are waiting for redescription. Recently, citizen science has become a rather popular tool for studying the distributions of various conspicuous species all around the world, and it has been applied also for H. halys (e.g., ÇERÇı et al. 2021, Chartois et al. 2021, VéTEK et al. 2021). Although this approach might be feasible in the expanding areas where the non-native $H$. halys is the only species of Halyomorpha present, the existence of a complex of externally indistinguishable species makes it inapplicable in south and southeast Asia, ranging from Pakistan and India to southern China, the Philippines, and the Malay Archipelago to the Lesser Sunda Islands. The situation in the latter vast area is further complicated by the imperfectly known distributi- 
onal range of the described species, unresolved taxonomic problems, including the presence of undescribed species, furthermore by a potential introduction of $H$. halys to further areas in the region. Future human-mediated introductions and invasions of other species of Halyomorpha into any area, including those already colonized by $H$. halys, also cannot be excluded unless they are prevented by a priority effect (e.g., FUKAMI 2015). Therefore all identifications of similarly looking species must be confirmed by examinations of genitalia, with involvement of an experienced taxonomist specialist if necessary. Photographs from areas like tropical Africa, Papua New Guinea, the Solomon Islands and New Caledonia inhabited by other Halyomorpha species must also be considered very carefully.

\section{Acknowledgements}

We are indebted to Herbert Zettel (NHMW), Gunvi Lindberg (NHRS), Amoret Spooner and Leonidas R. Davranoglou (OXUM) for providing access to specimens. We are also obliged to Igor Malenovský (Faculty of Science, Masaryk University, Brno, Czech Republic), Marcos RocaCusachs (Faculty of Biology, University of Barcelona, Catalonia, Spain) and Jing-Fu Tsai (Department of Biology, National Museum of Natural Science, Taichung, Taiwan) for valuable comments on the manuscript. The work of P. Kment was financially supported by Ministry of Culture of the Czech Republic (DKRVO 2019-2023/5.I.c, National Museum, 00023272). Salini is grateful to M. Nagesh (Director, ICAR-NBAIR, Bangalore, India) for the facilities extended for this work and the Science and Engineering Research Board (SERB), Department of Science and Technology, Government of India (CRG/2019/001619) for the financial support.

\section{References}

ABBASI Q. A. 1986: Morpho-taxonomic studies of the family Pentatomidae Leach, 1815 (Heteroptera: Pentatomorpha) of South Asia (Pakistan, Azad Kashmir and Bangladesh) with reference to the phylogeny of the group. Supplement of the Entomological Society of Karachi 5: 1-279.

ABBASI Q. A. \& AHMAD I. 1974: A new species of the genus $\mathrm{Ha}$ lyomorpha Mayr from East Bengal (Pentatomoidea, Pentatominae). Mushi 48 (7): 71-78.

AHMAD I. 1981: A revision of the superfamilies Coreoidea and Pentatomoidea (Heteroptera: Pentatomomorpha) from Pakistan, Azad Kashmir, and Bangladesh. Part I: Additions and corections [sic!] of coreid and pentatomid fauna with phylogenetic considerations. Supplement of the Entomological Society of Karachi 4 (1) [1979]: $1-113$.

AHMAD I., ABBASI Q. A. \& KHAN A. A. 1974: Generic and suprageneric keys with reference to a check list of Pentatomid fauna of Pakistan (Heteroptera: Pentatomoidea) with notes on their distribution and food plants. Supplement of the Entomological Society of Karachi 1: 1-103.

AHMAD I. \& KAMALUDDIN S. 1977: A new species of the genus Halyomorpha Mayr (Pentatomoidea: Pentatominae) from Pakistan. Karachi University Journal of Science 5 (1-2): 71-74.

AHMAD I., McPHERSON J. E., RAB N. \& BUNDY C. S. 2019: Systematic relationship between Piezodorus guildinii and P. hybneri (Hemiptera: Heteroptera: Pentatomidae) and diagnostic characters to separate species. Zootaxa 4613 (3): 443-462.

AHMAD I. \& ZAIDI R. H. 1989: A revision of the genus Halyomorpha Mayr (Hemiptera: Pentatomidae: Pentatominae: Carpocorini) from
Indo-Pakistan subcontinent with description of a new species from Potohar region of Pakistan and their cladistic analysis. Proceedings of Pakistan Congress of Zoology 9: 237-253.

ATKINSON E. T. 1888: Notes on Indian Rhynchota: Heteroptera, No. 3. Journal of the Asiatic Society of Bengal 57 (2): 1-72.

AUKEMA B., RIEGER CH. \& RABITSCH W. 2013: Catalogue of the Heteroptera of the Palaearctic Region. VI. Supplement. The Netherlands Entomological Society, Amsterdam, xxiii + 629 pp.

BEIER M. 1938: Heteroptera oder Wanzen. Pp. 2041-2204. In: KÜKENTHAL W. \& KRUMBACH T. (eds): Handbuch der Zoologie. Eine Naturgeschichte der Stämme des Tierreiches. Vierter Band, Zweite Hälfte. Insecta 2. Walter de Gruyter \& Co., Berlin, Leipzig, pp. 1385-2490.

BERGROTH E. 1892: Rhynchota æthiopica. Annales de la Société Entomologique de Belgique 36: 160-162.

BERGROTH E. 1908: Enumeratio Pentatomidarum post Catalogum bruxellensem descriptarum. Mémoires de la Société Entomologique de Belgique 15 (10): 131-200.

BERGROTH E. 1913: On a small collection of Hemiptera from north eastern French Congo. Annales de la Société Entomologique de Belgique 57: 237-239.

BERGROTH E. 1914: Descriptions of some Ethiopian Heteroptera with synonymical notes. Revue Zoologique Africaine 3: 448-461.

BERGROTH E. 1915: Hemiptera from the Bombay presidency. Journal of the Bombay Natural History Society 24: 170-179.

BERGROTH E. 1921: On Halyomorpha Mayr and allied genera. Notulae Entomologicae 1: 4-8

BISWAS B. \& BAL A. 2007: Insecta: Hemiptera: Heteroptera: Pentatomoidea. Pp. 301-319. In: Fauna of Andhra Pradesh, State Fauna Series, 5 (Part-3)-Insects. Zoological Survey of India, Kolkata, 544 pp.

BLACK G. M. 1968: Pentatomidae (Hemiptera, Heteroptera) collected by the Noona Dan Expedition in the Philippine, Bismarck and Solomon Islands. Entomologiske Meddelelser 36: 560-576.

BORISADE O. A., UWAIDEM Y. I. \& AYOTUNDE-OJO M. O. 2017: Arthropods associated with Amaranthus hybridus in Southwestern Nigeria and aggregation patterns of Gasteroclisus rhomboidalis, Hypolixus nubilosus (Coleoptera: Curculionidae) and Brown Marmorated Stink Bug, Halyomorpha halys (Hemiptera: Pentatomidae) in relation to host's morphology. Asian Journal of Advances in Agricultural Research 2 (1): 1-11.

BREDDIN G. 1899: Hemiptera Insulae Lombok in Museo Hamburgensi asservata adiectis speciebus nonnullis, quas continent collectio auctoris. Jahrbuch der Hamburgischen Wissenschaftlichen Anstalten 16 (2): 155-194. [Also issued as a separate reprint: 1899: pp. 1-40] BREDDIN G. 1900a: Hemiptera gesammelt von Professor Kükenthal im Malayischen Archipel. Abhandlungen Senckenbergischen Naturforschenden Gesellschaft 25: 139-202 + pl. IX.

BREDDIN G. 1900b: Hemiptera Sumatrana collecta a dom. Henrico Dohrn. Pars I. Stettiner Entomologische Zeitung 61: 275-336.

BREDDIN G. 1901: Die Hemipteren von Celebes. Ein Beitrag zur Faunistik der Insel. Abhandlungen der Naturforschenden Gesellschaft zu Halle 24: 1-213.

CACHAN P. 1952: Les Pentatomidae de Madagascar (Hemipteres Heteropteres). Mémoires de l'Institut Scientifique de Madagascar (E) 1 (2): 231-462, pls. 6-14.

ÇERÇİ B., KARATAŞ AH. \& KARATAŞ Ay. 2021: Insecta non gratae: New distribution records of eight alien bug (Hemiptera) species in Turkey with contributions of citizen science. Zootaxa 5057 (1): 1-28.

CHAKRABORTY S. P. \& GHOSH L. K. 1999: Insecta: Hemiptera: Heteroptera: Pentatomoidea. Pp. 391-429. In: ANONYMUS (ed.): Fauna of Meghalaya. Part 4. Zoological Survey of India, Kolkata, iv +485 pp.

CHARTOIS M., STREITO J.-C., PIERRE É., ARMAND J.-M., GAUDIN J. \& ROSSI J.-P. 2021: A crowdsourcing approach to track the expansion of the brown marmorated stinkbug Halyomorpha halys (Stål, 1855) in France. Biodiversity Data Journal 9 (e66335): 1-11.

DALLAS W. S. 1851: List of the specimens of hemipterous insects in the collection of the British Museum. Part 1. Trustees of the British Museum, London, $368 \mathrm{pp}$.

DISTANT W. L. 1879: Hemiptera from the North-eastern Frontier of India. Annals and Magazine of Natural History, Series 5 3: 44-53. 
DISTANT W. L. 1880: Notes on some exotic Hemiptera, with descriptions of new species. Entomologist's Monthly Magazine 16: 201-203.

DISTANT W. L. 1887: Contributions to a knowledge of Oriental Rhynchota. Part 1. Fam. Pentatomidæ. Transactions of the Entomological Society of London 1887 (3): 341-359 + pl. XII.

DISTANT W. L. 1890: Ethiopian Rhynchota in the collection of the Brussels Museum. Annales de la Société Entomologique de Belgique 34: li-1xi.

DISTANT W. L. 1893: On some allied Pentatomidæ, with synonymical notes. Annals and Magazine of Natural History, Series 611: 389-394.

DISTANT W. L. 1902: Rhynchota Vol. I, Heteroptera. In: BLANFORD W. T. (ed.): The Fauna of British India Including Ceylon and Burma. Taylor and Francis, London, xxxvii + 438 pp.

DISTANT W. L. 1914: Rhynchota from New Caledonia and the surrounding islands. Pp. 369-390 + pls. XI-XII. In: SARASIN F. \& ROUX J. (eds): Nova Caledonia. Forschungen in Neu-Caledonien und auf den Loyalty Inseln. A. Zoologie. Vol. 1. C. W. Kreidels Verlag, Wiesbaden, 449 pp + pls. I-XIV.

DISTANT W. L. 1918: Rhynchota. Vol. VII. Homoptera: Appendix. Heteroptera: Addenda. In: SHIPLEY A. E. \& MARSHALL A. K. (eds) The Fauna of British India Including Ceylon and Burma. Taylor and Francis, London, vii +210 pp.

DOHRN A. 1859: Catalogus Hemipterorum. Herrcke \& Lebeling, Stettin, ii +112 pp.

DOHRN A. 1860: Zur Heteropteren-Fauna Ceylon's. Entomologische Zeitung (Stettin) 21 (10-12): 399-409.

ELLENRIEDER C.A. M. M. M. von 1862: Eerste bijdrage tot de kennis der Hemipteren van den Indischen Archipel. [First contribution to the knowledge of Hemiptera of the Indian Archipelago]. Natuurkundig Tijdschrift voor Nederlandsch Indië 24: 130-176 + pls I-VI (in Dutch with Latin descriptions).

ESAKI T. 1955: Hemiptera. Pp. 155-228. In: SHIRAKI T., ESAKI T. \& TAKASHIMA H. (eds): Illustrated Pocket Book of the Insects in Colour. II. Hokuryukan, Tokyo, $7+318+60$ pp (in Japanese).

FABRICIUS J. C. 1794: Entomologia systematica emendata et aucta secundum classes, ordines, genera, species adjectis synonymis, locis, observationibus, descriptionibus. Vol. IV. Proft, Hafniae, v +472 pp.

FABRICIUS J. C. 1798: Supplementum entomologiae systematicae. Proft et Storch, Hafniae, $572 \mathrm{pp}$

FAIRMAIRE L. \& SIGNORET V. 1858: Ordre Hémiptères. Premiere Partie. In: Histoire naturelle des insectes et des arachnides récuelles pendant un voyage fait au Gabon en 1856 et 1857 par M. Henry C. Deyrolle. Archives Entomologiques (J. Thomson ed.) 2: 268-329.

FAÚNDEZ E. I. \& RIDER D. A. 2017: The brown marmorated stink bug Halyomorpha halys (Stål, 1855) (Heteroptera: Pentatomidae) in Chile. Arquivos Entomolóxicos 17: 305-307.

FAÚNDEZ E. I. \& RIDER D. A. 2018: Review of the genus Menestheus Stål, 1868 (Hemiptera: Heteroptera: Pentatomidae). Zootaxa 4407 (2): $275-280$

FAÚNDEZ E. I. \& RIDER D. A. 2019: A new genus and new species of Aeptini (Hemiptera: Heteroptera: Pentatomidae: Pentatominae) from Australia. Zootaxa 4658 (1): 189-192.

FUKAMI T. 2015: Historical contingency in community assembly: Integrating niches, species pools, and priority effects. Annual Review of Ecology, Evolution, and Systematics 46: 1-23.

GADALLA S. M. 2004: New records of Pentatomomorpha (Hemiptera) from Egypt. Journal of Union of Arab Biologists Cairo, A, Zoology 21: 43-58.

GAPUD V. P. 2015: The Philippine genus Stilbotes Stal and a new tribe of Asopinae (Hemiptera: Pentatomidae). Asia Life Sciences 24 (2): 1-5.

GARIEPY T. D., MUSOLIN D. L., KONJEVIĆ A., KARPUN N. N., ZAKHARCHENKO V. Y., ZHURAVLEVA E. N., TAVELLA L., BRUIN A. \& HAYE T. 2021: Diversity and distribution of cytochrome oxidase I (COI) haplotypes of the brown marmorated stink bug, Halyomorpha halys Stål (Hemiptera, Pentatomidae), along the eastern front of its invasive range in Eurasia. NeoBiota 68: 53-77.

GENEVCIUS B. C., GREVE C., KOEHLER S., SIMMONS R. B., RIDER D. A., GRAZIA J. \& SCHWERTNER C. F. 2021: Phylogeny of the stink bug tribe Chlorocorini (Heteroptera, Pentatomidae) based on DNA and morphological data: the evolution of key phenotypic traits. Systematic Entomology 46: 327-338.
GERSTAECKER A. 1892: Bestimmung der von Herrn. Dr. F. Stuhlmann in Ostafrika gesammelten Hemiptera. Jahrbuch der Hamburgischen Wissenschaftlichen Anstalten 9 (2): 45-58.

GHATE H. V. 2015: Rediscovery of the shieldbug Menedemus vittatus, with notes on $M$. hieroglyphicus (Heteroptera: Pentatomidae: Pentatominae: Sciocorini), from Pune, Maharashtra, India. Entomon 40 (4): 243-248.

GRAZIA J., PANIZZI A. R., GREVE C., SCHWERTNER C. F., CAMPOS L. A., GARBELOTTO T. DE A. \& FERNANDES J. A. M. 2015: Stink Bugs (Pentatomidae). Pp. 681-756. In: PANIZZI A. R. \& GRAZIA J. (eds): True Bugs (Heteroptera) of the Neotropics. Springer, Doderecht, Heidelberg, New York, London, xxii + 901 pp.

GUIDOTI M., SIMÕES F. L., RUSCHEL T. P., GONCALVES V. DA R., SOKOLOWICZ C. \& AGOSTI D. 2021: Using taxonomic treatments to assess an author's career: the impactful Jocélia Grazia. Zootaxa 4958 (1): 12-33.

HAMILTON G. C., AHN J. J., BU W.-J., LESKEY T. C., NIELSEN A. L., PARK Y.-L., RABITSCH W. \& HOELMER K. A. 2018: Halyomorpha halys (Stål). Pp. 243-292. In: MCPHERSON J. E. (ed.): Invasive stink bugs and related species (Pentatomoidea): Biology, higher systematics, semiochemistry, and management. CRC Press, Taylor \& Francis Group, Boca Raton, London, New York, xix +819 pp.

HASAN S. A. 1993: Three new species of the genus Halyomorpha Mayr (Heteroptera: Pentatomidae: Pentatominae) from the Malayan Subregion with phylogenetic considerations. Pakistan Journal of Zoology 25 (3): 209-216.

HASSAN M. E., MUKHERJEE P. \& BISWAS B. 2016: A new species of Aeschrocoris Bergroth (Hemiptera: Heteroptera: Pentatomidae: Pentatominae) from India. Munis Entomology and Zoology 11 (1): 246-249.

HERRICH-SCHÄFFER G. A. W. 1853: Alphabetisch synonymisches Verzeichniss der wanzenartigen Insecten nebst historischer Uebersicht der einschlägigen Literatur. J. L. Lotzbeck, Nürnberg, iv + 210 pp.

HEYDEN T. VAN DER, SACI A. \& DIOLI P. 2021: First record of the brown marmorated stink bug Halyomorpha halys Stål, 1855) in Algeria and its presence in North Africa (Heteroptera: Pentatomidae). Revista Gaditana de Entomología 12 (1): 147-154.

HIGGINS L. G. 1963: Dates of publication of the Novara Reise. Journal of the Society for the Bibliography of Natural History 4 (3): 153-159.

HOEBEKE R. E. \& CARTER M. E. 2003: Halyomorpha halys (Stål) (Heteroptera: Pentatomidae): a polyphagous plant pest from Asia newly detected in North America. Proceedings of the Entomological Society of Washington 105: 225-237.

HOFFMANN W. E. 1932: A list of the Pentatomidae, Plataspidae, and Coreidae (order Hemiptera) of China, Korea, and Indo-China. Journal of the Pan-Pacific Research Institution 7 (1): 6-11.

HSIAO T.-Y. \& ZHENG L.-Y. 1977: Family Pentatomidae. Pp. 53-158, 297-300, pls 5-25. In: HSIAO T.-Y., REN S.-Z., ZHENG L.-Y., JING H.-L. \& LIU S.-L. (eds): A handbook for the determination of the Chinese Hemiptera-Heteroptera. Vol. I. Science Press, Beijing, iii +330 pp +52 pls (in Chinese with English summary).

ICZN [= INTERNATIONAL COMMISSION ON ZOOLOGICAL NOMENCLATURE] 1999: International Code of Zoological Nomenclature. Fourth edition. International Trust for Zoological Nomenclature, London, 306 pp

ISHIKAWA T. \& MORIYA S. 2019: A review of the stink bug genus Plautia Stål from Japan (Hemiptera, Heteroptera, Pentatomidae). Zootaxa 4564 (2): 470-490.

JEANNEL R. 1913: Voyage de Ch. Alluaud et R. Jeannel en Afrique Orientale (1911-1912). Résultats scientifiques. Insectes Hémiptères. I. Pentatomidae. Albert Schulz, Paris, 114 pp + pls. i-iv.

JOSIFOV M. V. \& KERZHNER I. M. 1978: Heteroptera aus Korea II. Teil (Aradidae, Berytidae, Lygaeidae, Pyrrhocoridae, Rhopalidae, Alydidae, Coreidae, Urostylidae, Acanthosomatidae, Scutelleridae, Pentatomidae, Cydnidae, Plataspidae). Fragmenta Faunistica 23 (9): 137-196.

KIRKALDY G. W. 1907: A note on the authorship of the "Hope Catalogues," etc. Annales de la Société Entomologique de Belgique $\mathbf{5 1}$ (11): 310 .

KIRKALDY G. W. 1909: Catalogue of the Hemiptera (Heteroptera) with biological and anatomical references, lists of foodplants and parasites, 
etc. Prefaced by a discussion on Nomenclature and an analytical table of families. Vol. I. Cimicidae. Felix L. Dames, Berlin, xl + 392 pp.

KMENT P. 2015: Two new genera of Madagascan Pentatominae (Hemiptera: Heteroptera: Pentatomidae). Acta Entomologica Musei Nationalis Pragae 55 (2): 591-624.

KMENT P. \& BAENA M. 2015: A redescription of the endemic Madagascan genus Tricompastes (Hemiptera: Heteroptera: Pentatomidae). Zootaxa 4044 (1): 65-78.

KMENT P. \& GARBELOTTO T. DE A. 2016: Discimita linnavuorii, a new genus and species of Afrotropical Pentatominae resembling Neotropical Discocephalinae (Hemiptera: Heteroptera: Pentatomidae) Entomologica Americana 122 (1-2): 199-211.

KMENT P., HEMALA V. \& MALENOVSKÝ I. 2019: Scanning the Hyocephalidae: details of their external morphology with respect to phylogenetic relationships within Eutrichophora (Hemiptera: Heteroptera). Acta Entomologica Musei Nationalis Pragae 59 (2): 423-441.

KMENT P. \& RÉDEI D. 2018: A revision of the types of Heteroptera species described by Géza Horváth based on specimens from collections of Ladislav Duda and Emil Holub. Acta Entomologica Musei Nationalis Pragae 58 (2): 275-295.

KMENT P. \& RIDER D. A. 2015: On the synonymy of Dymantis Stål, 1861 and Eomyrochea Linnavuori, 1982 and resulting nomenclatural changes (Hemiptera: Heteroptera: Pentatomidae). Zootaxa 4058 (2): 278-286.

KMENT P., SALINI S. \& AHMED Z. 2021: Halyomorpha picus (Hemiptera: Heteroptera: Pentatomidae): first confirmed record from Pakistan and two new junior synonyms. Zootaxa 5060 (3): 429-438.

LESKEY T. C. \& NIELSEN A. L. 2018: The impact of the invasive brown marmorated stink bug in North America and Europe: History, biology, ecology, and management. Annual Review of Entomology 63: 599-618.

LESTON D. 1952: Notes on the Ethiopian Pentatomoidea (Hemiptera).-V. On the specimens collected by Mr. A. L. Capener, mainly in Natal. Annals and Magazine of Natural History, Series 12 5: 512-520.

LESTON D. 1955: Pentatomoidea (Hemiptera): New species and synonomy. Annals and Magazine of Natural History, Series 12 8: 698-704.

LETHIERRY L. \& SEVERIN G. 1893: Catalogue général des Hémiptères. Vol. 1. Pentatomidae. F. Hayez, Bruxelles, $\mathrm{x}+286 \mathrm{pp}$.

LIN Y-J. \& ZHANG SH.-M. 1993: Hemiptera: Pentatomoidea. Pp. 106-139. In: HUANG C.-M. (ed.): The Series of the Bioresources Expedition to the Longqi Mountain Nature Reserve: Animals of Longqi Mountain. China Forestry Publishing House, Beijing, $2+2$ $+3+6+8+1130$ pp.

LINNAVUORI R. E. 1975: Hemiptera of the Sudan, with remarks on some species of the adjacent countries 5. Pentatomidae. Boletim da Sociedade Portuguesa de Ciências Naturais, $2 .{ }^{A}$ Série 15: 5-128.

LINNAVUORI R. E. 1982: Pentatomidae and Acanthosomidae [sic!] of Nigeria and the Ivory Coast, with remarks on species of the adjacent countries in West and Central Africa. Acta Zoologica Fennica 163: $1-176$.

LIU G.-Q. \& WANG H.-J. 2004: Hemiptera: Scutelleridae, Tessaratomidae, Dinidoridae and Pentatomidae. Pp. 173-189. In: YANG X.-K. (ed.): Insects from Shiwandashan Area of Guangxi. China Forestry Publishing House, Beijing, $2+3+3+668+$ [2] pp. (in Chinese).

MAYR G. L. 1864: Diagnosen neuer Hemipteren. Verhandlungen des Zoologisch-Botanischen Gesellschaft in Wien 14 (4): 903-914.

MAYR G. L. 1866: Hemiptera. Pp. 1-204, pls. I-V. In: Reise der Österreichischen Fregatte Novara um die Erde in den Jahren 1857, 1858, 1859 unter den Befehlen des Commodore B. von Wüllerstorf-Urbair. Zoologischer Theil. Zweiter Band. I. B. Abtheilung. Kaiserliche Akademie der Wissenschaften, Wien, vi + 1-388, pls. I-IV + 1-204, pls. I-V.

MEDLER J. T. 1980: Insects of Nigeria - check list and bibliography. Memoirs of the American Entomological Institute 30: i-vii + 1-919.

MOTSCHULSKY V. DE 1863: Essai d'un catalogue des insectes de l'ile Ceylan. Bulletin de la Société Impériale des Naturalistes de Moscou 36 (3): $73-115+$ pl. II.

NIKAM K. N. \& MORE S. V. 2016: Diversity of insects from Jangamhatti area, Chandgad, Kolhapur district of Maharashtra. Biolife 4 (1): 209-212.

NONNAIZAB (ed.) 1986: Fauna of Inner Mongolia (Hemiptera: Heteroptera). Vol. I., Book 1. Inner Mongolia People's Press, Huhehot,
$469 \mathrm{pp}$ (in Chinese). [A reprint edition from 1989, erroneously bearing the year ' 1988 ' in its title page, has been seen.]

OSHANIN B. 1906: Verzeichnis der palaearktischen Hemipteren mit besonderer Berücksichtigung ihrer Verteilung im Russischen Reiche. I. Band. Heteroptera. I. Lieferung. Pentatomidae-Lygaeidae. Ezhegodnik Zoologicheskago Muzeya Imperatorskoy Akademii Nauk' 11 (Supplement): i-1xxiv + 1-393.

OSHANIN B. 1912: Katalog der paläarktischen Hemipteren (Heteroptera, Homoptera-Auchenorhyncha und Psylloideae). R. Friedlander and Sohn, Berlin, xvi $+187 \mathrm{pp}$.

RÉDEI D. 2017: Tmetopis revisited: redescription, new synonymies, and revised tribal placement (Hemiptera: Heteroptera: Pentatomidae). Zootaxa 4303 (2): 231-242.

RÉDEI D. \& TSAI J.-F. 2021: Zhengica cornuta gen. nov., sp. nov., a new genus and species of Pentatomidae from East Asia (Hemiptera: Heteroptera). Zootaxa 5071 (2): 271-282.

RIDER D. A. 2006: Family Pentatomidae Leach, 1815. Pp. 233-402. In: AUKEMA B. \& RIEGER CH. (eds.): Catalogue of the Heteroptera of the Palaearctic Region. Vol. 5. The Netherlands Entomological Society, Amsterdam, xiii +550 pp.

RIDER D. A. 2012: The Heteroptera (Hemiptera) of North Dakota I: Pentatomomorpha: Pentatomoidea. Great Lakes Entomologist $\mathbf{4 5}$ (3-4): 312-380.

RIDER D. A. 2016: Aeliavuori linnacostatus, a new genus and species of Pentatomidae from the Democratic Republic of the Congo (Hemiptera: Heteroptera: Pentatomidae: Pentatominae: Carpocorini). Entomologica Americana 122 (1-2): 212-219.

RIDER D. A. \& EGER J. E. JR. 1995: Names proposed and taxonomic publications by Lawrence H. Rolston. Journal of the New York Entomological Society 103: 350-359.

RIDER D. A. \& ROLSTON L. H. 1995: Nomenclatural changes in the Pentatomidae (Hemiptera-Heteroptera). Proceedings of the Entomological Society of Washington 97 (4): 845-855.

RIDER D. A., SCHWERTNER C. F., VILÍMOVÁ J., RÉDEI D., KMENT P. \& THOMAS D. B. 2018: Higher systematics of the Pentatomoidea. Pp. 25-201. In: McPHERSON J. E. (ed.): Invasive Stink Bugs and related species (Pentatomoidea). Biology, Higher Systematics, Semiochemistry and Management. CRC Press, Taylor \& Francis Group, Boca Raton, London, New York, xix + 819 pp.

RIDER D. A., ZHENG L.-Y. \& KERZHNER I. M. 2002: Checklist and nomenclatural notes on the Chinese Pentatomidae (Heteroptera). II. Pentatominae. Zoosystematica Rossica 11 (1): 135-153.

ROCA-CUSACHS M. \& JUNG S. 2019: Redefining Stagonomus Gorski based on morphological and molecular data (Pentatomidae: Eysarcorini). Zootaxa 4658 (2): 368-374

ROCA-CUSACHS M. \& JUNG S.-H. 2020: Pentatomidae. Arthropoda: Insecta: Hemiptera. Flora and Fauna of Korea, Insect fauna of Korea, Vol. 9, No. 8. National Institute of Biological Resources, Incheon, $[\mathrm{i}]+131 \mathrm{pp}$.

ROCA-CUSACHS M., KIM J.-G., KIM K.-H., LEE S.-G. \& JUNG S.-H. 2019: Spockia tagala gen. and sp. nov. a new monotypic genus of Asopinae (Hemiptera: Heteroptera: Pentatomidae) from the Philippines. Zootaxa 4613 (1): 181-186.

ROCA-CUSACHS M., KIM J.-G., LEE H.-D., LEE G.-S. \& JUNG S.-H. 2018: Revision of genus Stilbotes Stål (Hemiptera: Pentatomoidea: Pentatomidae: Asopinae) with description of a new species. Zootaxa 4425 (2): 385-392.

ROCA-CUSACHS M., KIM J.-G., SCHWERTNER C. F., GRAZIA J., EGER J. \& JUNG S. 2021a: Opening Pandora's box: Molecular phylogeny of the shield bugs (Hemiptera: Heteroptera: Pentatomidae) reveals great incongruences in its internal classification. Systematic Entomology, https://doi.org/10.1111/syen.12514

ROCA-CUSACHS M., RIDER D. A. \& JUNG S.-H. 2021b: New genus and new species of Pentatomidae from Borneo (Hemiptera: Heteroptera). Zootaxa 4958 (1): 560-569.

ROELL T., LEMAITRE V. A. \& WEBB M. D. 2019: Revision of the African shieldbug genus Afrius Stål, 1870 (Hemiptera: Heteroptera: Pentatomidae: Asopinae). European Journal of Taxonomy 520: 1-44.

ROLSTON L. H. \& RIDER D. A. 1985: Names proposed and taxonomic publications by Herbert Ruckes (1895-1965). Journal of the New York Entomological Society 93: 1173-1181. 
SALINI S. 2016a: Redescription of Dardjilingia Yang (Hemiptera: Heteroptera: Pentatomidae) from India. Zootaxa 4144 (1): 131-137.

SALINI S. 2016b: Redescription of a predatory stink bug, Amyotea malabarica (Fabricius, 1775) (Hemiptera: Pentatomidae: Asopinae). Journal of Biological Control 30 (4): 240-247.

SALINI S. 2017a: First record of Brachycoris Stål (Hemiptera: Heteroptera: Pentatomidae) in India, with description of a new species. Zootaxa 4236 (3): 563-572.

SALINI S. 2017b: First record of Neojurtina typica from India (Hemiptera: Heteroptera: Pentatomidae). Journal of Threatened Taxa 9 (4): 10133-10137.

SALINI S. 2019: Revision of the genus Halys (Hemiptera: Pentatomidae) with description of a new species from India. Zootaxa 4586 (2): 351-375.

SALINI S. 2020: Pentatomidae (Hemiptera: Heteroptera: Pentatomoidea) of India. Pp. 121-146. In: RAMANI S., MOHANRAJ P. \& YESHWANTH H. M. (eds): Indian insects. Diversity and science. CRC Press, Taylor \& Francis Group, Boca Raton, London, New York, xxii + $450 \mathrm{pp}$.

SALINI S., DAVID K. J. \& PRATHEEPA M. 2021a: Does India have the invasive brown marmorated stink bug, Halyomorpha halys (Stål). Current Science 120 (2): 268-269.

SALINI S. \& KMENT P. 2021: The genera Agathocles and Surenus (Hemiptera: Heteroptera: Pentatomidae): tribal reassessment, redescription, new synonyms, and description of two new species. Zootaxa 4958 (1): 510-559.

SALINI S., RABBANI M. K., AMALA U. \& MAHENDIRAN G. 2021d: First record of the genus Lodosocoris Ahmad \& Afzal (Hemiptera: Heteroptera: Pentatomidae: Halyini) from India with description of a new species. Zootaxa 5072 (1): 53-62.

SALINI S., RABBANI M. K., GRACY R. G., DAVID K. J. \& SACHIN K. 2021b: A bizarre pentatomid, Phricodus hystrix (Germer [sic!], 1838) (Hemiptera: Pentatomidae) on Ocimum sp. Indian Entomologist 2 (2): $27-38$.

SALINI S., RABBANI M. K. \& SINGH S. 2021c: Taxonomic notes on Sarju Ghauri, 1977 (Hemiptera: Heteroptera: Pentatomidae) with description of a new species from India. Zootaxa 4951 (2): 283-303.

SALINI S. \& ROCA-CUSACHS M. 2021: Review of the Oriental species of the genus Brachycerocoris Costa, 1863 (Hemiptera: Pentatomoidea: Pentatomidae: Podopinae s.1.) with description of two new species. Zootaxa 5040 (4): 507-527.

SALINI S. \& SCHMIDT C. 2018: Revision of genus Acrozangis Breddin (Hemiptera: Pentatomidae: Pentatominae) with description of a new species from India. Zootaxa 4413 (3): 507-523.

SALINI S. \& VIRAKTAMATH C. A. 2015: Genera of Pentatomidae (Hemiptera: Pentatomoidea) from south India - an illustrated key to genera and checklist of species. Zootaxa 3924 (1): 1-76.

SCHERZER K. 1861a: Reise der Österreichischen Fregatte Novara um die Erde in den Jahren 1857, 1858, 1859 unter den Befehlen des Commodore B. von Wüllerstorf-Urbair. Erster Band. Karl Gerold's Sohn, Wien, i-x + 1-368 + 1-37 pp., pls. I-VII. Appendices I-V, map.

SCHERZER K. 1861b: Narrative of the circumnavigation of the globe by the Austrian Frigate Novara, (Commodore B. von Wullerstorf-Urbair, undertaken by Order of the Imperial Government, in the years 1857 , 1858, 1859, under the immediate auspices of his I. and R. Highness the archduke Ferdinand Maximilian, commander-in-chief of the Austrian Navy. Vol. I. Saunders, Otley, and Co., London, i-1+1-484 pp.

SCHOUTEDEN H. 1905: Expédition du Baron C. von Erlanger en Abyssinie et au pays des Somalis. Hémiptères-Hétéroptères. Annales de la Société Entomologique de Belgique 49: 11-16.

SCHOUTEDEN H. 1913: Cimicidæ et Coreidæ recueillis au Congo par le Dr. J. Bequaert. Revue Zoologique Africaine 2 (2): 189-202.

SCHOUTEDEN H. 1933: Resultats scientifique du voyage aux Indes Orientales Néerlandaises de LL. AA. RR. le Prince et la Princesse Léopold de Belgique. Hemiptera-Heteroptera. Mémoires du Musée Royal d'Histoire Naturelle de Belgique 4 (8): 43-70.

SHAIKH A. M., MEMON N., SHAH M. A., BIRMANI N. A. \& IQBAL Y. 2015: Apodiphus balochiensis - addition of a species in genus Apodiphus Spinola (Hemiptera: Pentatomidae: Pentatominae: Halyini) from Quetta (Baluchistan, Pakistan). Sindh University Research Journal (Science Series) 47 (2): 331-334.
SIGNORET V. 1881: 'Liste des Hémiptères reçueillis en Chine par M. Collin de Plancy'. Bulletin des Séances de la Société Entomologique de France 1881 (5): 45-47. [Re-published in Annales de la Société Entomologique de France, Série 61 (1): xli-xlii.]

SILVA J. S. T. F. DA, GRAZIA J. \& BARÃO K. 2021: Redescription of Steleocoris Mayr, 1864 and Theloris Thunberg, 1783 (Hemiptera: Pentatomidae), two poorly known African stink bugs. Zootaxa 4938 (4): 475-486.

STÅL C. 1855: Nya Hemiptera. [New Hemiptera]. Öfversigt af Kongliga Vetenskaps-Akademiens Förhandlingar 12 (4): 181-192 (in Swedish and Latin).

STÅL C. 1856: Hemipterologiska bidrag. [Hemipterological contribution]. Öfversigt af Kongliga Vetenskaps-Akademiens Förhandlingar 13 (3): 51-68, plate I (in Swedish and Latin).

STÅL C. 1865: Hemiptera nova vel minus cognita. Annales de la Société Entomologique de France, Série 45 (2): 163-188.

STÅL C. 1868a: Bidrag till Hemipterernas systematik. [Contribution to the systematics of Hemiptera]. Öfversigt af Kongliga Vetenskaps-Akademiens Förhandlingar 24 (7) [1867]: 491-560 (in Latin, Swedish title).

STÅL C. 1868b: Hemiptera Fabriciana. Kongliga Svenska Vetenskap-Akademiens Handlingar (Ny Följd) 7 (11): 1-148 (in Swedish and Latin).

STÅL C. 1876: Enumeratio Hemipterorum. Bidrag till en förenteckning over alla hittils kända Hemiptera, jemte systematiska meddelanden. 5. [Checklist of Hemiptera. Contribution to a list of all hitherto known Hemiptera, along with systematic notes. 5]. Kongliga Svenska Vetenskaps-Akademiens Handligar (Ny Följd) 14 (4): 1-162 (in Latin, Swedish title).

STICHEL W. 1961: Illustrierte Bestimmungstabellen der Wanzen. II. Europa. (Hemiptera-Heteroptera Europae). Vol. 4. Heft 24. Part 1. Liste der Paläarktischen Arten. Pentatomomorpha II. Stichel, Berlin-Hermsdorf, 32 pp. [pp. 737-768]

STICHEL W. 1962: Verzeichnis der paläarktischen Hemiptera-Heteroptera. IV. Pentatomomorpha (Coreoidea-Pentatomoidea). Stichel, Berlin-Hermsdorf, pp. 187-362.

SWANSON D. R. 2012: An updated synopsis of the Pentatomoidea (Heteroptera) of Michigan. Great Lakes Entomologist 45 (3-4): 263-311.

TANG T.-H. 1935: Family Pentatomidae. Pp. 275-382. In: WU C. F. F.: Catalogus insectorum sinensium. Volume II. Fan Memorial Institute of Biology, Peiping, 634 pp.

THOMAS D. B., JR. 1994: Taxonomic synopsis of the Old World asopine genera (Heteroptera: Pentatomidae). Insecta Mundi 8 (3-4): 145-212.

TSAI J. F., RÉDEI D., YEH G. F. \& YANG M. M. 2011: Jewel bugs of Taiwan (Heteroptera: Scutelleridae). National Chung Hsing University, Taichung, $309 \mathrm{pp}$.

UHLER P. R. 1860: Hemiptera of the North Pacific Exploring Expedition under Com'rs Rodgers and Ringgold. Proceedings of the Academy of Natural Sciences of Philadelphia 12 (6) [1861]: 221-231.

VÉTEK G., MELIFRONIDOU-PANTELIDOU A., KOUKKOULARIDOU D. \& MARTINOU A. 2021: Initiation of a monitoring programme for early detection of Halyomorpha halys in Cyprus by using pheromone-baited traps and involving citizen science. Management of Biological Invasions 12 (2): 331-343.

VÉTEK G., PAPP V., HALTRICH A. \& RÉDEI D. 2014: First record of the brown marmorated stink bug, Halyomorpha halys (Hemiptera: Heteroptera: Pentatomidae), in Hungary, with description of the genitalia of both sexes. Zootaxa 3780 (1): 194-200.

VILLIERS A. 1952: Hémiptères de l'Afrique Noire. (Punaises et cigales). Initiations Africaines, Vol. 9. Institut Français d'Afrique Noire, Dakar, $256 \mathrm{pp}$.

VILLIERS A. 1967: Contribution à la faune du Congo (Brazzaville). Mission A. Villiers et A. Descarpentries. LXVII. Hémiptères Pentatomidae. Bulletin de l'Institut Français d'Afrique Noire, Série A 29 (4): 1784-1811.

WALKER F. 1859: List of Ceylon insects. Pp. 269-293. In: TENNENT J. E. (ed.): Ceylon. An account of the island physical, historical, and topographical with notices of its natural history, antiquities and productions. Vol. I. Fourth edition. Longman, Green, Longman, and Roberts, London, xxxix $+619 \mathrm{pp}$.

WALKER F. 1867a: Catalogue of the specimens of heteropterous He- 
miptera in the collection of the British Museum. Part I. Scutata. E. Newman, London, pp. 1-240.

WALKER F. 1867b: Catalogue of the specimens of heteropterous Hemiptera in the collection of the British Museum. Part II. Scutata. E. Newman, London, pp. 241-417.

WANG H.-J. \& LIU G.-Q. 2005: Hemiptera: Scutelleridae, Tessaratomidae, Dinidoridae and Pentatomidae. Pp. 279-292. In: YANG X.-K. (ed.): Insect fauna of Middle-West Qinling Range and South Mountains of Gansu Province. Science Press, Beijing, ix + 1055 pp (in Chinese).

WERMELINGER B., WYNIGER D. \& FORSTER B. 2008: First records of an invasive bug in Europe: Halyomorpha halys Stål (Heteroptera: Pentatomidae), a new pest on woody ornamentals and fruit trees? Mitteilungen der Schweizerischen Entomologischen Gesellschaft 81: 1-8.

[WESTWOOD J. O.] 1837: A catalogue of Hemiptera in the collection of the Rev. F. W. Hope [...], with short Latin diagnoses of the new species. Bridgewater, London, 46 pp. [About authorship see KIRKALDY (1907).]
WOLFF J. F. 1802: Icones Cimicum descriptionibus illustratae. Vol. 3. Johann Jacob Palm, Erlangen, pp. 85-126 + pls IX-XII.

XU SH.-W., WU Y.-F., LIU Y.-Q., ZHAO P., CHEN ZH., SONG F., LI H. \& CAI W.-ZH. 2021: Comparative mitogenomics and phylogenetic analyses of Pentatomoidea (Hemiptera: Heteroptera). Genes 12 (1306): 1-12.

ZAIDI R. H. \& SHAUKAT S. SH. 1993: Taxometric studies of five closely related genera of the tribe Carpocorini Stal (Hemiptera: Pentatominae) from the Indo-Pakistan subcontinent. Bangladesh Journal of Zoology 21 (1): 59-66.

ZAIDI R. H., SHAUKAT S. SH. \& AHMAD I. 1990: Taxometric studies on the tribe Carpocorini Stål (Pentatomidae: Pentatominae) from Oriental region. Indian Journal of Zoological Spectrum 1: 41-47.

ZHAO Q., BU W.-J. \& LIU G.-Q. 2016: The genus Cecyrina Walker, 1867, with the description of two new species (Hemiptera: Pentatomidae: Asopinae). Zootaxa 4114 (3): 309-319.

ZHOU Y.-Y. \& RÉDEI D. 2020: From lanceolate to plate-like: Gross morphology, terminology, and evolutionary trends of the trichophoran ovipositor. Arthropod Structure and Development 54 (100914): 1-29. 